\title{
PEMBANGUNAN SOSIAL-POLITIK INDONESIA: MENILIK MASALAH KLASIK DI KALIMANTAN TENGAH
}

\author{
Mochammad Doddy Syahirul Alam \\ Jurusan Administrasi Negara Universitas Palangka Raya
}

\begin{abstract}
Abstrak : Pembangunan sosial politik di Provinsi Kalimantan Tengah saat ini terus berlangsung secara berkesinambungan. Beberapa sektor andalan dalam pembangunan meliputi sektor perkebunan, pertambangan, dan kehutanan masih menjadi idola dan sekaligus sebagai kontributor terbesar pendapatan daerah. Perkembangan ketiga sektor secara tidak langsung memberikan multiplayer efect bagi kondisi sosial politik di Kalteng. Dari aspek sosial perkembangan dan dinamika pembangunan akan memberikan tekanan masyarakat lokal untu mampu bersaing dengan masyarakat pendatang, masalah pemerataan kesempatan berusaha dan pemerataan pendapatan menjadi salah satu isu krusial dalam perkembangannya. Dari aspek politik kebijakan pemerintah daerah dalam pengelolaan sumber daya alam semakin hari semakin menuai kritikan dari berbagai elemen masyarakat khususnya terhadap dampak yang ditimbulkan dari kegiatan perkebunan dan pertambangan. Eksploitasi dibidang perkebunan dan pertambangan mulai memberikan dampak negatif kepada masyarakat dan lingkungan hidup Kalimantan Tengah.
\end{abstract}

Keywords: Pembangunan Sosial Politik, Kalimantan Tengah

\section{Pendahuluan}

Pembangunan bisa diartikan sebagai proses memajukan atau memperbaiki suatu keadaan melalui berbagai tahap secara terencana dan berkesinambungan (Conyers dan Hills, 1989; Jameson dan Wilber, 1979). Sebagai suatu perubahan terencana dan berkesinambungan, pembangunan pada hakekatnya bertujuan untuk memperbaiki dan meningkatkan kualitas hidup manusia. Menurut Todaro (1997), kemajuan ekonomi merupakan komponen penting dalam pembangunan. Namun demikian, pembangunan bukanlah semata-mata fenomena ekonomi. Pembangunan harus ditujukan lebih dari sekedar peningkatan kemakmuran manusia secara material dan finansial. Pembangunan harus dipandang sebagai 
proses multi-dimensional yang melibatkan reorganisasi dan reorientasi sistem ekonomi dan sosial secara menyeluruh. Disamping upaya-upaya peningkatan pendapatan secara ekonomi, pembangunan juga memerlukan perubahanperubahan struktur-struktur sosial, politik, sikap-sikap masyarakat, termasuk kebiasaan dan keyakinan. Selain itu pembangunan juga tidak dapat dipisahkan dari proses global. Pada intinya, pembangunan akan memberikan hasil yang optimal apabila memperhatikan berbagai dimensi secara seimbang dan proporsional.

Krisis multi-dimensi yang dihadapi bangsa Indonesia sejak tahun 1998 tidak hanya menyangkut aspek ekonomi, tetapi juga merambat kepada aspek pembangunan sosial-politik. Ternyata, kondisi ekonomi dan sosial-politik bangsa Indonesia sangat rapuh dan rentan terhadap terpaan arus globalisasi. Hal itu menuntut semua komponen bangsa untuk mengkaji ulang paradigma pembangunan ekonomi dan tidak terkecuali paradigma pembangunan sosialpolitik yang penting dan mendesak untuk disusun mengingat semakin banyaknya permasalahan sosial-politik yang muncul sebagai dampak pembangunan.

Masalah-masalah seperti kemiskinan, kriminalitas, kerusakan lingkungan, dan isu-isu dehumanisasi yang lain memperlihatkan sepertinya pembangunan di Indonesia jalan di tempat. Namun menilik ke setiap daerah, akan dapat terlihat gambaran yang lebih jelas dan komprehensif seperti apa pembangunan yang selama ini sedang terjadi. Seperti halnya dengan yang terjadi di Kalimantan Tengah. Melalui adanya Focus Group Discussion (FGD) yang dihadiri oleh pejabat daerah, akademisi, masyarakat, birokrat pemerintah daerah, NGO, swasta 
serta dilanjutkan melalui depth interview terhadap budayawan setempat, setidaknya dapat diperoleh gambaran masalah pembangunan sosial-politik apa saja yang sedang terjadi di Kalimantan Tengah sehingga dapat menjadi suatu masukan yang berarti bagi perencanaan strategis pembangunan sosial-politik Indonesia walaupun belum dapat digeneralisir dan membutuhkan penelitian yang lebih mendalam.

\section{Perubahan Pembangunan Sosial-Politik Di Kalimantan Tengah}

Pembangunan Sosial dapat ditafsirkan sebagai pembangunan yang melibatkan manusia secara langsung. Seperti telah diuraikan, bahwa pembangunan ekonomi yang bertujuan untuk meningkatkan pendapatan rata-rata perorangan (per capita income) tidak selamanya meningkatkan pendapatan perorangan secara merata. Dan logika teori ekonomi pembangunan tentang "penetesan ke bawah" sudah semakin menampakkan kelemahan-kelamahannya. Proses penetesan ke bawah tidak terjadi dengan sendirinya tanpa kemampuan kelompok masyarakat berpenghasilan rendah untuk aktif meraih peluang-peluang yang muncul atau menciptakan peluangnya sendiri untuk memperoleh penghasilan. Golongan ekonomi kuat tidak dapat diharapkan secara sukarela menyalurkan sumberdayanya kepada golongan ekonomi lemah. Pemerataan tidak berjalan otomatis, dan tidak cukup hanya dengan menghimbau dan mengandalkan niat baik golongan ekonomi kuat untuk menolong masyarakat miskin.

Menarik garis kemunculan pembangunan sosial sebagai suatu paradigma tidak terlepas dari pola pembangunan yang pernah dilakukan di negara-negara 
maju. Kesadaran itu muncul sekitar tahun 1960-an, justru karena terlihat begitu banyak kemiskinan dan pengangguran. Sehingga sekitar tahun 1970-an pembangunan ekonomi didefinisikan kembali dalam rangka pengurangan atau pemberantasan kemiskinan, ketidakmerataan, dan pengangguran dalam hubungannya dengan perekonomian yang sedang tumbuh. Profesor Dudley Seers seperti dikutip Todaro menjelaskan:

Pertanyaan-pertanyaan yang harus dipermasalahkan tentang pembangunan suatu negara adalah: Apa yang terjadi dengan kemiskinan? dengan pengangguran? dengan ketidakmerataan? Apabila ketiga hal itu semakin menurun maka pasti pembangunan sedang terjadi di negara tersebut. Apabila satu atau dua dari ketiga masalah tersebut ternyata menjadi semakin buruk, apalagi kalau semuanya, maka agak aneh kalau kita menyebut pembangunan, meskipun pendapatan per kapita meningkat dua kali (M. P. Todaro, 1989)

Secara sistemik, tingkat kemajuan dari suatu sistem tidak lepas dari keberadaan komponen yang paling lemah. Ini berarti tingkat kemajuan suatu negara juga akan ditentukan oleh kondisi-kondisi daerah tertinggal yang ada yang dalam hal ini yaitu desa/ kelurahan. ${ }^{1}$ Pada tahun 2010 jumlah penduduk miskin di Kalimantan Tengah sebanyak 164.221 jiwa (6,77\%) dan pada September 2011 sebanyak 150.021 jiwa $(6,64 \%)$ dengan pencapaian tersebut telah memposisikan Kalteng pada urutan ke tujuh terendah tingkat kemiskinan di Indonesia setelah (secara berurutan) DKI Jakarta, Bali, Bangka Belitung, Kalimantan Selatan, Banten,dan Kalimantan Timur. Bila dipahami lebih dalam, data yang dilansir oleh Badan Pusat Statistik Kalteng tersebut, isu pentingnya bukanlah pada selisih

\footnotetext{
${ }^{1}$ Istilah kelurahan dipakai untuk menunjuk struktur pemerintah desa di wilayah kotamadya, dengan pimpinannya Lurah. H. Khairuddin, Pembangunan Masyarakat: Tinjauan Aspek: Sosiologi, Ekonomi, dan Perencanaan, Liberty Yogyakarta, Yogyakarta, 2000. Hal. 3
} 
besaran atau tingkat penurunan dari tahun ke tahun, melainkan pada fenomena pengonsentrasian penduduk miskin di daerah perdesaan dan hampir $67 \%$ penduduk Kalteng berada di daerah perdesaan. ${ }^{2}$

Perkembangan penanaman modal di Kalimantan Tengah mengalami perubahan/peningkatan yang luar biasa. Jumlah perusahaan Penanaman Modal Asing tahun 2010 sebanyak 183 buah perusahaan dengan rencana investasi 18,5 Milyar Dollar lebih dan realisasi 5,0 Milyar Dollar lebih. Sedangkan Penanaman Modal Dalam Negeri sebanyak 191 buah perusahaan dengan rencana investasi sebesar 186,0 Triliun Rupiah lebih dan realisasi sebesar 19,8 Triliun Rupiah lebih. Dominasi perusahaan berada pada bidang perkebunan kelapa sawit dan pertambangan batu bara. Di bagian barat, terhampar tanaman perkebunan kelapa sawit seluas sekitar $900.000 \mathrm{Ha}$, perkebunan karet tersebar dihampir semua kawasan, sedangkan potensi tambang batu bara berada di bagian timur-utara, dengan jumlah potensi cadangan sekitar 4,8 milyar ton. ${ }^{3}$ Dengan melihat data tersebut diatas, Kalimantan Tengah berpotensi menjadi provinsi yang maju dan sejahtera. Begitu juga dengan ibukota provinsi Palangka Raya yang di isukan akan menjadi ibukota pemerintahan Indonesia. Dalam Rencana Pembangunan Jangka Menengah Daerah (RPJMD) Prov. Kalteng, sudah termuat untuk mulai berkoordinasi dengan pihak terkait guna menghasilkan tata ruang yang baik serta kaijan tentang potensi sumberdaya, sarana dan prasarana. ${ }^{4}$

\footnotetext{
${ }^{2}$ Panusunan Siregar, Penduduk Desa Yang Termiskinkan, Harian Kalteng Pos, 16 Januari 2012.,Hal.11

${ }^{3}$ Rencana Pembangunan Jangka Menengah Daerah Provinsi Kalimantan Tengah Tahun 20102015, Pemprov Kalteng,. Hal. 48-49,IV-5-IV-6

${ }^{4}$ Ibid,. Hal. VII-1-VII-2
} 
Perbandingan antara jumlah penduduk miskin dengan realisasi investasi di Kalimantan Tengah memberikan gambaran adanya permasalahan yang terjadi dalam pembangunan daerah. Seharusnya proses perubahan yang dimaksudkan adalah ke arah yang lebih baik, tetapi sebaliknya proses perubahan yang terjadi di dominasi oleh masalah-masalah yang muncul satu persatu ke permukaan dan jika tidak diatasi dengan baik dapat membahayakan proses pembangunan yang dimaksudkan. Apa saja masalah tersebut:

1. Persoalan Rencana Tata Ruang Wilayah Provinsi (RTRWP) masih menjadi polemik di Komisi IV DPR RI, bukan berarti masalah tersebut menjadi berlarut-larut. Belum jelas kapan ujung dari penyelesaiannya. Jadi, memang harus segera dituntaskan, karena menyangkut hajat hidup masyarakat luas dalam hal sertifikasi lahan. Selain itu, dampak lainnya adalah kerugian perusahaan perkebunan dan penghasilan asli daerah (PAD) dari sektor pajak bumi dan bangunan, jika status hukum lahan belum ada kejelasan. Hal tersebut yang perlu dipikirkan oleh Komisi IV DPR RI, agar masalah RTRWP dapat diselesaikan lebih cepat. Terlebih lagi, dari jumlah 33 provinsi di negeri ini, sebagian besar penyelesaian RTRWP-nya belum tuntas dibahas di Komisi IV DPR RI. Contohnya, Provinsi Kalimantan Tengah (Kalteng), sekitar 236.000 hektar area Kajian Lingkungan Hutan Strategis (KLH), sejauh ini belum rampung pembahasannya. "Yang menjadi ganjalan terhadap RTRWP Kalteng adalah area lahan seluas 236 ribu hektare, yang masih menjadi perdebatan di Komisi IV" Dampak dari hal tersebut, kalau DPR tidak memutuskan segera, berarti Badan Pertanahan Nasional (BPN) tidak dapat 
menerbitkan sertifikat yang selama ini diimpikan sebagian besar masyarakat Kalteng. Akibatnya, pemerintah pun tidak bisa menindaklanjuti proses persertifikatan, karena menunggu RTRWP Kalteng dibahas DPR RI. Diharapkan ada penegasan MA agar Perda No 8 Tahun 2003 bisa diterapkan. “Area yang masih jadi perdebatan di DPR RI, ternyata kawasannya sudah berupa perumahan dan perkantoran. Misalnya, Kantor Gubernur, masih dalam status Hutan Produksi," akibat kendala penerbitan sertifikat, pinjaman warga ke perbankan tidak akan bisa terealisasikan. Dengan begitu, tentu saja, sangat merugikan masyarakat Bumi Tambun Bungai yang diwacanakan menjadi Ibukota Negara.

2. Investasi Sawit Terancam: Beberapa waktu lalu pengurus Gabungan Pengusaha Kelapa Sawit Indonesia (Gapki) mengeluhkan persoalan RTRWP di Kalteng. Akibat belum ada kejelasan hukum atas lahan yang dijadikan areal perkebunan kelapa sawit, investor terancam rugi. Apalagi dari 1,2 juta hektar lahan perkebunan sawit, 960.000 hektar masih kategori bermasalah dalam hal RTRWP. Ketua Gapki Kalteng, Dwi Darmawan, menyesali masih berlarutnya penyelesaian RTRWP di Kalteng. Sebab, tidak sedikit anggotanya mengalami kerugian investasi, yakni pemusnahan pembibitan sawit lantaran sudah terlalu tua. "Bibit itu terpaksa dimusnahkan, tidak bisa dilanjutkan, lantaran status lahannya belum ada kejelasan hukum. Hal ini yang sangat merugikan anggota kami," paparnya. Dijelaskan Dwi, hampir 90 persen anggotanya mengalami kerugian akibat belum selesainya RTRWP di Kalteng. Sekaligus tidak bisa menjalankan program revitalisasi perkebunan untuk rakyat. "Karena BPN 
tidak bisa memproses sertifikat, maka pihak perbankan pun tidak akan mengucurkan kredit tanpa agunan. Ini salah satu kendala program revitalisasi perkebunan," ungkapnya. Dwi menambahkan, belum tuntasnya masalah RTRWP di Kalteng, maka kepastian hukum lahan perkebunan sawit seluas 960.000 hektar dari total 1,2 juta hektar akan menjadi persoalan panjang. Baik, bagi masyarakat, maupun investor sawit. "Jika lahan lokasi perkebunan sawit seluas itu dikembalikan statusnya sebagai hutan, maka sebanyak 288.000 orang pekerja sawit akan menjadi pengangguran. Saya berharap pemerintah perlu memikirkan hal tersebut," jelasnya. Harapan serupa juga disampaikan Ketua Umum Gapki Pusat, Joefly J Bachroeny. Menurut dia, pemerintah pusat segera menyelesaikan RTRWP Kalteng demi kelangsungan usaha perkebunan kelapa sawit di wilayah tersebut. "Ketika bertatap muka dengan Presiden, beliau menjelaskan penyelesaian tata ruang provinsi akan dilakukan secara bijaksana, tidak akan merugikan investasi yang telah selama ini dilakukan sesuai peraturan yang berlaku," jelas Joefly kepada wartawan beberapa waktu lalu. Dia berharap, pemerintah daerah dan pusat bisa berkoordinasi tentang persoalan tersebut. Juga, tentang pemberian izin investasi sawit, Wali Kota/Bupati menggunakan dasar hukum Perda Nomor 8 Tahun 2003 tentang RTRWP Kalteng.

3. Moratorium Izin Kelapa Sawit dan Tambang: Kerusakan hutan di Kalimantan Tengah akhirnya disadari dan ditindaklanjuti oleh Gubernur Kalimantan Tengah Agustin Teras Narang. Gubernur menyatakan sudah meneken surat keputusan tentang moratorium (penghentian sementara) pembukaan hutan 
untuk kelapa sawit. Penegasan ini dikatakan Teras Narang saat pembukaan kongres ke IV Sawit Watch di Hotel Aquarius, Palangkaraya, Sabtu, 17 November 2012. Menurut dia, untuk menggodok masalah perda ini, Pemprov Kalteng banyak mendapatkan bantuan dari sejumlah LSM dan pemerhati lingkungan. "Saya banyak mendapatkan masukan dan juga kritik. Semuanya saya terima, termasuk kritikan itu," kata dia. Asal masukan tersebut kontruktif, konsitional, dan ada solusinya. "Pemerhati sawit banyak yang membantu saya untuk membuat perda tentang perkebunanan. Apa kelemahan, apa yang harus diperbaiki," ia menambahkan. Karena itu, menurut Teras Narang, untuk meminimalisir kerusakan lingkungan yang ditimbulkan, sekarang ini dia sudah mengeluarkan kebijakan penghentian sementara (moratorium) perizinan perkebunan kelapa sawit dan pertambangan. Moratorium itu sangat penting untuk penyempurnaan perizinan yang telah dikeluarkan daerah. Dengan adanya moratorium, ia ingin para bupati itu mau melihat ke belakang agar tidak membuka dan memberikan izin sembarangan. Sebelum keluar keputusan moratorium, pemerintah Kalimantan Tengah sudah bekerja sama dengan Unit Kerja Presiden Bidang Pengawasan dan Pengendalian Pembangunan (UKP4) yang menyangkut masalah audit dengan perizinan. Sebagai kabupaten percontohan, ditetapkan Kabupaten Barito Selatan untuk pengukuhan kawasan hutan. Untuk masalah audit perizinan kabupaten, percontohannya ada tiga, yakni Kapuas, Barito Selatan, dan Kotawaringin Timur. Data Badan Pertanahan Nasional Provinsi Kalimantan Tengah menyebutkan luas Izin Usaha Perkebunan yang dikeluarkan oleh 
pemerintah daerah seluas 2.793.794,94 hektar untuk dikuasai sekitar 234 perusahaan sawit. Di lain pihak, luas perkebunan yang baru mendapatkan Hak Guna Usaha (HGU) sekitar 783.629,97 hektar. "Dari data ini sektar 81 perusahaan sawit yang belum memiliki HGU," ujar Kepala Seksi Pengaturan dan Penataan Tanah Badan Pertanahan Nasional, Sudarman.

4. Kepala Kantor Badan Perencanaan Pembangunan Daerah (Bappeda) Kalimantan Tengah Ir. H. Syahrin Daulay mengatakan, tercatat enam permasalahan yang kini menjadi perhatian pihaknya terkait rencana pembangunan jangka menengah daerah (RPJMD) setempat. "Pada Perda RPJMD No.1/2011, ada enam permasalahan dan empat isu strategis penting bagi pembangunan Kalteng 2010-2015". Menurutnya, keenam permasalahan itu adalah penyediaan infrastruktur, pengembangan ekonomi lokal, kualitas dan keterjangkauan pendidikan, kesejahteraan sosial, pengembangan kapasitas birokrasi, dan permasalahan pengelolaan sumber daya alam. Sedangkan empat isu strategis meliputi kebijakan internasional, nasional, regional, dan komitmen internasional terhadap adaptasi dan mitigasi perubahan iklim global, ujarnya. Diutarakannya, untuk permasalahan infrastruktur adalah belum terwujudnya sistem dan jaringan transportasi, komunikasi, dan informatika yang mendukung aktivitas ekonomi kerakyatan. Masih terbatasnya infrastruktur pengairan yang mendukung ketahanan pangan. "Selain itu, belum optimalnya pemanfaatan sumber energi untuk masyarakat, masih rendahnya kualitas infrastruktur terutama prasarana jalan dan jembatan, serta prasarana lalu lintas air antarkabupaten/kota," ucapnya. Luas wilayah 
Kalteng yang dihuni penduduk relatif sedikit dan terpencar-pencar, menyebabkan tingkat pelayanannya menjadi sulit dilakukan. Dijelaskannya, masalah pengembangan ekonomi lokal, pengelolaan pertanian, perkebunan, perikanan, peternakan dan kehutanan belum dikelola secara professional dan sebagian besar masih dikelola secara tradisional. "Masalah lainnya adalah masih rendahnya produktivitas pertanian, perkebunan, perikanan, peternakan dan kehutanan. Belum terselenggaranya sistem perekonomian kerakyatan yang terpadu, masih rendahknya kualitas pengembangan pemasaran pariwisata dan pengelolaan detinasi wisata dan masih rendahnya kualitas kelembagaan dalam pelayanan penanaman modal," katanya. Kemudian, lanjut dia, begitu juga masih rendahnya kualitas iklim usaha, promosi dan kerja sama investasi, terbatasnya akses koperasi dan UMKM kepada sumberdaya produktif, masih rendahnya produktivitas dan daya saing produk koperasi dan UMKM juga menjadi masalah dalam pengembangan ekonomi lokal. "Bahkan belum optimalnya penyelenggaraan kemitraan usaha antara ekonomi kerakyatan dengan ekonomi berskala besar, pengelolaan sumber daya alam (SDA) yang tidak memenuhi kaidah-kaidah teknis, menyebabkan terjadinya degradasi lingkungan yang sangat berpengaruh terhadap sektor-sektor lain," ucapnya menandaskan.

5. Bupati Kotawaringin Barat (Kobar) Ujang Iskandar menilai Provinsi Kalimantan Tengah (Kalteng) layak dimekarkan menjadi tiga provinsi, yakni wilayah tengah, barat, dan wilayah utara. "Kalimantan Tengah seharusnya bisa menjadi tiga provinsi," kata Bupati Kotawaringin Barat Ujang Iskandar, di 
Pangkalan Bun, Kamis. Dalam kesempatan yang sama, Bupati Murung Raya, wilayah Utara Kalimantan Tengah, Willy M Yoseph, juga menilai pemekaran bisa dilakukan guna kepentingan kesejahteraan, seperti mengatasi kemiskinan, kebodohan, serta keterisolasian. Menurut Ujang, bila semangat kedua daerah itu bertemu yakni antara barat dan utara maka Kalimantan Tengah yang kini beribukota di wilayah Tengah di Kota Palangkaraya, seharusnya dapat dimekarkan sesuai kebutuhan daerah. Selama ini di wilayah Kotawaringin baik Kotawaringin Timur, Kotawaringin Barat, Seruyan, Lamandau dan Sukamara banyak aspirasi yang menginginkan pembentukan daerah otonom baru berupa Provinsi Kotawaringin Raya. Sementara aspirasi sebagian warga Barito, meliputi Murung Raya, Barito Utara, Barito Selatan, Barito Timur juga menyuarakan aspirasi serupa membentuk Provinsi Barito Raya. Ujang menegaskan yang paling penting saat ini adalah antara Kalimantan Tengah wilayah utara dan wilayah barat harus menunjukkan tekad bersama memajukan Kalteng di daerah masing-masing. Sebelumnya, pengamat hukum dan pemerintahan Universitas Palangka Raya, Rakhmadiansyah Bagan SH Mhum menilai wacana pemekaran Provinsi Kalteng menjadi tiga daerah otonom tetap layak diperjuangkan sepanjang dilakukan dalam koridor hukum dan ketentuan perundangan yang berlaku. "Bila memang telah memenuhi ketentuan, sah-sah saja banyak pihak yang ingin memperjuangkan pemekaran wilayah menjadi provinsi baru yakni Kotawaringin Raya dan Barito Raya," kata Rakhmadiansyah Bagan. Menurut dia, wacana pemekaran wilayah di Kalteng, terutama Provinsi Kotawaringin Raya yang akhir-akhir ini menguat, 
secara teknis kewilayahan telah memadai karena membawahi lima daerah otonom. Sementara wacana pemekaran wilayah hulu Kalteng menjadi Provinsi Barito Raya, masih terkendala dalam aspek tersebut, karena baru mencakup empat daerah otonom. Sehingga masih membutuhkan upaya lain untuk memenuhi aspek kewilayahan itu, misalnya dengan membentuk daerah otonom baru semacam Kota Ampah (wilayah Kabupaten Barito timur), kata Rakhmadiansyah yang juga Dosen Fakultas Hukum Unpar. "Wacana pemekaran Barito Raya menurut catatan sejarah sebenarnya telah mengemuka sejak sebelum terbentuknya Provinsi Kalteng yakni sekitar tahun 1957. Namun hingga kini masih sulit direalisasikan," jelasnya. Di sisi lain, wacana Provinsi Kotawaringin Raya yang mengemuka belakangan ini justru lebih kuat dan memenuhi aturan hukum dan perundangan. "Tidak ada masalah diwacanakan, bahkan untuk Kotawaringin Raya juga bisa diimplementasikan hingga ada ‘aksi`. Persoalannya apakah dibutuhkan atau tidak. Kalau tidak dibutuhkan kenapa harus buru-buru," ungkapnya

6. Belum terpenuhinya kebutuhan listrik masih menjadi permasalahan serius di wilayah Kalteng. Terlebih hingga sekarang ketersediaan pasokan listrik hanya sebesar 125.941 MW (Mega Watt). Namun, daya terpasang pembangkit listrik di Kalteng saat ini hanya sebesar 90.713 MW. Sehingga, selisihnya diperoleh dari suplai sistem Kalselteng yang dikirim melalui jaringan transmisi $150 \mathrm{KV}$ (Kilo Volt) baik ke gardu induk Kapuas, Pulang Pisau dan Palangka Raya. Ditambah daya dari mesin-mesin sewa yang ada di Palangka Raya, Kasongan dan Sampit dengan total 141.358 MW. Wakil Gubernur Kalteng Ir H Achmad 
Diran mengungkapkan, kebutuhan energi listrik di Kalteng kedepan diperkirakan naik sebesar kurang lebih 15 persen. Hal ini sejalan dengan pesatnya pembangunan di segala sektor di Kalteng khususnya Palangka Raya. "Langkah-langkah guna memenuhi kebutuhan tersebut, diantaranya telah dimulainya pembangunan Pembangkit Listrik Tenaga Uap (PLTU) di Pulang Pisau 2X60 MW, pembangunan PLTU Sampit 2X25 MW". Hal ini, kata Diran, juga didukung dengan percepatan pembangunan transmisi tegangan tinggi 150 KV Palangka Raya - Sampit dan 2012 Sampit Pangkalan Bun. Selain itu juga pembangunan PLTU 2X100 MW di Kabupaten Katingan. Sedangkan, kondisi kelistrikan desa di Kalteng sampai akhir 2011, kata Diran, dari 1.510 desa dengan jumlah rumah tangga 617.052 yang sudah menikmati penerangan listrik baru sebanyak 949 desa. Sedangkan desa dengan jumlah rumah tangga berlistrik 379.263 atau rasio desa berlistrik pada akhir tahun 2011 sebesar 65.6 persen. rasio elektrifikasi atau rumah tangga berlistrik sampai akhir tahun 2011 sebesar 61.4 persen. Saat ini, katanya, ada sekitar 561 desa pada 237.789 rumah tangga yang belum menikmati penerangan listrik di Kalteng. Diran menanggapi adanya keluhan masyarakat terhadap tingginya biaya pasang baru maupun pemasangan instalasi. Dikatakan dia, saat ini pemprov sedang mempersiapkan edaran yang mengatur tentang besarnya biaya pemasangan instalasi di tiap-tiap kabupaten/kota. "Untuk biaya pasang baru telah ditetapkan secara resmi oleh PT PLN sebesar Rp 337.000 untuk daya 450 VA (Volt Ampera)," ujarnya. Dikatakan Diran, untuk mempercepat pembangunan listrik desa, sejak 2011 lalu pemerintah dari 
tingkat pusat hingga daerah bersama PLN sejak 2011 telah membuat kesepakatan bahwa pada 2012 ini akan berupaya melistriki 5000 rumah tangga per tahunnya. Diran menyebutkan, rasio elektrifikasi di bawah 50 persen mampu melistriki minimal 3000 rumah tangga per tahun. Sedangkan, rasio elektrifikasinya di atas 50 persen akan melistriki minimal 200 rumah tangga per tahun. Dia mengatakan, PLN beserta Satuan Kerja (Satker) Listrik Perdesaan melistriki 50.000 rumah tangga per tahun. Sehingga, harapannya, pada 2015 rasio elektrifikasi kalteng dapat mencapai 100 persen. Sebelumnya, Fraksi Partai Persatuan Pembangunan (F-PPP) DPRD Kalteng menyampaikan keluhan masyarakat terkait ketersediaan kelistrikan. Pasalnya, ketergantungan pada kelistrikan dirasa semakin tinggi dan ketersediaan kelistrikan dirasa belum merata. "Kondisi tersebut disebabkan oleh banyaknya peralatan yang penggunaannya harus dikoneksikan dengan listrik," kata jurubicara FPPP Awaludin Noor terkait Raperda Ketenagalistrikan dan Pemanfaatan Energi. Politikus ini menyampaikan, keterbatasan listrik dengan freksuensi kebutuhan semakin hari semakin tinggi. Sehingga, tambah Awaludin, perlu ada pemikiran komprehensif guna mengatasi keterbatasan tersebut. "Kami berharap, ketersediaannya dapat memenuhi kebutuhan, akibatnya, pemenuhan kebutuhan listrik berbatas," katanya. "Kebutuhan berbatas tersebut maksudnya adalah pelaksanaan atas keadilan dan pemerataan. Untuk pemenuhan kebutuhan berbatas itulah, regulasi dari Gubernur harusnya menuju ke arah tersebut," imbuhnya. Disampaikannya juga, dalam konteks ketersediaan energi, Kalteng setidaknya memiliki sumberdaya air guna pembangkit listrik. 
Ketersediaannya, kata Awaludin, mesti dapat perhatian guna pemanfaatan pemenuhan kebutuhan listrik. "Ke arah itulah seharusnya rancangan peraturan daerah dilatarbelakangi," tegasnya.

\section{Masalah Klasik Yang Perlu Kejelasan}

Permasalahan pembangunan tersebut hanya mungkin tercapai apabila pembangunan ekonomi dan pembangunan sosial-politik dalam pelaksanaannya dilakukan secara sinergis dan berkesinambungan. Dalam kaitan ini, implikasinya adalah perlunya jaminan tentang: Pertama, Persamaan dalam menikmati hak-hak ekonomi, sosial-politik, dan budaya; negara dapat melakukan batasan-batasan terhadap pelaksanaan hak ini melalui pengaturan dalam undang-undang sejauh tidak bertentangan dengan hakekatnya dan sematamata demi tujuan memajukan kesejahteraan umum dalam masyarakat demokratis dan Kedua, Memberikan jaminan kepada setiap orang atas standar penghidupan yang layak, bebas dari kelaparan, dan menikmati standar hidup yang memadai yang dapat dicapai untuk kesehatan jasmani dan rohani.

Permasalahan yang terjadi di Kalteng selama ini merupakan masalah yang klasik yang berusaha untuk diselesaikan dengan baik. Masalah kemiskinan di Kalteng terutama penduduk yang terkonsentrasi di pedesaan lebih mengarah kepada persoalan keterisolasian infrastruktur. Oleh karena itu Pemprov Kalteng melalui visi Gubernurnya berusaha untuk membuka isolasi tiap-tiap daerah yang sangat tertinggal tersebut. Berbagai program kedaerahan berbasis pemberdayaan masyarakat seperti Program Mamangun Tuntang Mahaga Lewu (PM2L)/ Program 
Membangun dan Menjaga/Memelihara Desa/Kelurahan terus dilakukan agar Desa-desa tertinggal menjadi maju dan sejahtera. Demikian pula dalam hal pendidikan dan kesehatan. Ada program Kalteng Harati/ Kalteng Pintar dan Kalteng Barigas/Kalteng Sehat serta berbagai program lainnya dari tiap-tiap daerah. Meskipun demikian adanya nuansa kepentingan politis masih melekat di setiap program-program tersebut. Sebagai contoh; program pengentasan kemiskinan yang dibuat oleh pemprov juga dibuat oleh pemkab/kota. Padahal seharusnya program-program tersebut harus saling bersinergi dan saling berkesinambungan, program "keroyokan" dari pemprov dan pemkab/kota terhadap kemiskinan setidaknya memberikan pengaruh yang signifikan terhadap angka kemiskinan di Kalteng setelah Program tersebut tidak lagi berjalan.

Masalah klasik berikutnya adalah masalah listrik. Kalteng yang kaya akan sumber daya alam sepertinya hanya dibiarkan saja oleh pemerintah pusat ketika masih sentralisasi. Sulit untuk Kalteng dapat berkembang jika listrik masih menjadi masalah hingga saat ini. Tidak hanya di kota saja, sampai ke pelosok pun listrik masih menjadi permasalahan. Masyarakat sering mengeluh listrik yang "mati-hidup" sementara pembayaran listrik tidak boleh mengalami keterlambatan. Selanjutnya masalah klasik yaitu ketidakjelasan permasalahan tanah. Masyarakat banyak mengeluh adanya keterbatasan dalam memaksimalkan hasil hutan akhirakhir ini. Sejak adanya larangan dan sanksi terhadap tindakan illegal logging, illegal fishing dan illegal mining, menyebabkan usaha rakyat yang bergantung pada hal tersebut menjadi bangkrut. Belum lagi tanah-tanah adat maupun warisan turun-temurun yang sulit untuk diperlihatkan kejelasan melalui sertifikat hak 
milik menjadi bermasalah tatkala perusahaan besar swasta baik itu perkebunan maupun tambang melakukan pengambil alihan hak sesuai dengan Izin Prinsip yang telah diperoleh dari pemkab.

Masalah klasik yang terakhir adalah kian mengemukanya wacana pemekaran daerah. Wacana pemekaran daerah kerap kali juga menjadi bahan jualan dalam pemilihan langsung kepala daerah (Pilkada Gubernur). Sejak terbentuknya Provinsi Kalteng, masalah letak ibukota sempat mencuat sebelum ditetapkannya Palangka Raya sebagai ibukota. Mereka yang kurang puas akan kemajuan dan kesejahteraan pembangunan ekonomi, sosial-politik di Kalteng memilih dan mendukung untuk Kalteng dimekarkan menjadi tiga provinsi. Secara alasan untuk kesejahteraan masyarakat dapat diterima. Namun ada gambaran lain yang dapat dilihat yaitu mulai tumbuhnya keretakan persatuan sesama suku Dayak di Kalteng.

\section{Kesimpulan}

Pembangunan Sosial-Politik merupakan aspek penting selain dari pembangunan ekonomi. Betapa pun tingginya angka pertumbuhan ekonomi namun masyarakat masih mengeluhkan pencapaian kesejahteraan yang adil dan merata maka hal tersebut belum memberikan pengaruh yang berarti bagi masyarakat secara keseluruhan. Perubahan pembangunan sosial-politik di Kalimantan Tengah masih diwarnai dengan persoalan klasik yang sejak pemerintahan masih sentralistis hingga desentralisasi kini belum terselesaikan dengan baik. Untuk itu peran pemerintah daerah dan pusat dalam memberi porsi 
perhatian yang lebih untuk kemajuan Kalteng sangat dinantikan oleh masyarakat. Jika itu nyata dalam tindakan dan dapat terlihat bukti konkretnya. Keluhankeluhan masyarakat Kalteng yang kerap kali dapat kita dengar dan dengan mudah kita dapati ketika pertanyaan diajukan, lambat laun akan berganti dengan apresiasi dan kebanggaan akan kemajuan daerah. Bukan tidak mungkin isu-isu kedaerahan yang dapat memunculkan konflik berangsur-angsur hilang dengan sendirinya.

\section{Referensi:}

Indiahono, Dwiyanto. 2009. Kebijakan Publik Berbasis Dynamic Policy Analisys. Yogyakarta: Penerbit Gava Media

Khairuddin. H. 2000.Pembangunan Masyarakat: Tinjauan Aspek: Sosiologi, Ekonomi, dan Perencanaan. Yogyakarta: Liberty Yogyakarta

Suharto, Edi. 2008 Analisis Kebijakan Publik: Panduan Praktis Mengkaji Masalah dan Kebijakan Sosial(Edisi Revisi). Bandung: Penerbit CV. Alfabeta

Rencana Pembangunan Jangka Menengah Daerah Provinsi Kalimantan Tengah Tahun 2010-2015, Pemprov Kalteng 2010

Tantangan Pembangunan Sosial Di Indonesia, Penyunting: Dr. Didiet Widiowati, Pusat Pengkajian Pengolahan Data dan Informasi (P3DI), Sekretariat Jenderal DPR RI 2009

http://www.kaltengpos.web.id/?menu=detail_atas\&idm=5641

http://www.kalimantan-news.com/berita.php?idb=4325

http://www.tempo.co/read/news/2012/11/09/090440778/Akhir-Bulan-KonferensiKelapa-Sawit-Digelar

http://www.antaranews.com/view/?i=1244745887\&c=NAS\&s=UMM 


\title{
KEBIJAKAN PEMERINTAH PADA PERKEMBANGAN AGRIBISNIS \\ DALAM PEMBANGUNAN EKONOMI DAERAH \\ RINTO ALEXANDRO \\ PRODI PENDIDIKAN EKONOMI FKIP - UNPAR
}

\begin{abstract}
Abstrak : Otonomi daerah adalah kewenangan daerah otonom untuk mengatur dan mengurus kepentingan masyarakat setempat menurut prakarsa sendiri berdasarkan aspirasi masyarakat sesuai dengan peraturan perundang-undangan (pasal 1 huruf (h) UU Nomor 22 Tahun 1999 tentang Pemerintahan Daerah). Saat ini hampir seluruh ekonomi daerah di Indonesia berbasis pada sistem agribisnis baik dilihat dari pendapatan domestik regional bruto (PDRB), penyerapan tenaga kerja, penguasaan teknologi, maupun struktur ekspor. Karena itu, strategi pembangunan ekonomi daerah yang paling tepat dan efektif adalah melalui pembangunan sistem agribisnis.
\end{abstract}

Keywords : Otonomi Daerah, Perkembangan Agribisnis

\section{Pendahuluan}

Perbangunan ekonomi yang sentralistis dimasa lalu, mengakibatkan terjadinya krisis multidimensi yang dialami bangsa Indonesia, khususnya krisis dibidang ekonomi. Krisis ekonomi yang terjadi merupakan akibat dari masalah fundamental dan keadaan khusus. Masalah fundamental adalah tantangan internal berupa kesenjangan yang ditandai oleh adanya pengangguran dan kemiskinan, sedangkan tantangan eksternal adalah upaya meningkatkan daya saing menghadapi era perdagangan bebas. Keadaan khusus adalah bencana alam kekeringan yang datang bersamaan dengan krisis moneter yang merembet dari negara tetangga. Krisis ekonomi ditandai melemahnya nilai tukar uang dalam negeri terhadap mata uang asing (Gunawan Sumodiningrat, 2000). 
Hal tersebut bukan gagal membangun perekonomian nasional yang kokoh, tetapi justru telah menciptakan disparitas ekonomi antar daerah dan antar golongan masyarakat di negara kita. Disparitas ekonomi yang terjadi sudah sangat mengkhawatirkan, karena selain telah memicu kecemburuan dan kerusuhan sosial, juga telah menimbulkan gejala disintegrasi berbangsa dan bernegara. Dewasa ini pemerintah memang telah mulai semakin memperhatikan pembangunan ekonomi daerah melalui jargon-jargon ekonomi politik seperti desentralisasi ekonomi, otonomi daerah, ekonomi kerakyatan dan pemberdayaan usaha kecil, menengah dan koperasi. Namun hingga saat ini belum jelas formatnya dan bagaimana implementasi konkritnya masih kita tunggu hasilnya. Bahkan apabila ditelaah lebih jauh, kadangkala kebijaksanaan makro ekonomi yang diterapkan justru tidak konsisten dan bertentangan dengan upaya pengembangan ekonomi daerah..

Kenyataan telah membuktikan dan menyadarkan kita semua akan pentingnya peran strategis sektor pertanian sebagai pilar penyangga atau basis utama ekonomi nasional dalam upaya penanggulangan dampak krisis yang lebih parah. Sektor pertanian rakyat serta usaha kecil dan menengaj relatif mampu bertahan dalam menghadapi krisis ekonomi dan menyelamatkan negara kita dari situasi yang lebih parah. Disamping pendekatan kemitraan dan penguatan jaringan, akan disinergikan pula dengan pendekatan peningkatan nilai tambah produksi pada usaha-usaha kecil yang berorientasi pada pasar/ekspor sesuai kompetensi ekonomi lokal daerahnya (Departemen 
Perindustrian dan perdagangan, dan Badan Perencanaan Pembangunan Nasional, 2000).

Sudah saatnya pembangunan ekonomi daerah yang menyangkut sebagian besar kepentingan ekonomi rakyat banyak tidak berhenti pada retorika saja, melainkan harus sesegera mungkin diwujudkan dalam aksi nyata dan dukungan kebijaksanaan makro ekonomi. Hal ini antara lain diwujudkan melalui penerapan konsep pengembangan agropolitan dan agribisnis dalam pembangunan ekonomi daerah atau pengembangan ekonomi lokal.

\section{Pengertian Desentralisasi}

Desentralisasi adalah pendelegasian wewenang dalam membuat keputusan dan kebijakan kepada manajer atau orang-orang yang berada pada level bawah dalam suatu struktur organisasi. Pada saat sekarang ini banyak perusahaan atau organisasi yang memilih serta menerapkan sistem desentralisasi karena dapat memperbaiki serta meningkatkan efektifitas dan produktivitas suatu organisasi.

2. Pengertian Otonomi Daerah

Otonomi daerah adalah kewenangan daerah otonomi untuk mengatur dan mengurus kepentingan masyarakat setempat menurut prakarsa sendiri berdasarkan aspirasi masyarakat sesuai dengan peraturan perundangundangan.

Pengertian "otonom" secara bahasa adalah "berdiri sendiri" atau "dengan pemerintahan sendiri". Sedangkan "daerah" adalah suatu "wilayah" atau "lingkungan pemerintah". Dengan demikian pengertian 
secara istilah "otonomi daerah" adalah wewenang/kekuasaan pada suatu wilayah/daerah yang mengantur dan mengelola untuk kepentingan wilayah/daerah masyarakat itu sendiri. Pengertian yang lebih luas lagi adalah wewenang/kekuasaan pada suatu wilayah/daerah yang mengatur dan mengelola untuk kepentingan wilayah/daerah masyarakat itu sendiri mulai dari ekonomi, politik, dan penganturan perimbangan keuangan termasuk penganturan sosial, budaya, dan ideologi yang sesuai dengan tradisi adat istiadat daerah lingkungannya.

3. Pengertian Agribisnis

Agribisnis merupakan suatu sistem yang terdiri atas subsistem hulu, usaha tani, hilir, dan penunjang. Menurut Saragih dalam Pasaribu (1999), batasan agribisnis adalah sistem yang utuh dan saling terkait di antara seluruh kegiatan ekonomi (yaitu subsistem agribisnis hulu, subsistem agribisnis budidaya, subsistem agribisnis hilir, subsistem jasa penunjang agribisnis) yang terkait langsung dengan pertanian.

\section{Pembangunan Ekonomi dengan Sistem Desentralisasi Ekonomi atau}

\section{Otonomi Daerah.}

Salah satu desentralisasi yang paling banyak disoroti dan paling berpengaruh terhadap perkembangan daerah adalah desentralisasi fiskal yang merupakan bagian penting dalam implementasi otonomi daerah. Kebijakan fiskal pada dasarnya adalah alat atau instrumen pemerintah yang sangat penting peranannya dalam sistem perekonomian. Instrumen 
fiskal itu berguna untuk mendorong pertumbuhan ekonomi, memperluas basis kegiatan ekonomi berbagai sektor, dan secara khusus memperluas lapangan usaha untuk menurunkan tingkat pengangguran. Dengan kebijakan fiskal, pemerintah dapat memanfaatkan sumber daya ekonomi untuk menyelesaikan berbagai permasalahan ekonomi yang dikehendakinya. Kebijakan fiskal juga sekaligus sebagai kesempatan emas untuk memberikan sinyal, baik bagi pelaku ekonomi, dunia usaha, investor, maupun yang lainnya.

Selama beberapa dekade banyak Negara Berkembang dan Negara Maju mencoba untuk menerapkan desentralisasi fiskal dengan tujuan untuk mengatasi ketidak efektifan dan ketidak efisienan pemerintahan, ketidakstabilan makro ekonomi, serta meningkatkan pertumbuhan ekonominya. Sebagian ahli menyatakan bahwa sasaran utama desentralisasi fiskal adalah dapat membantu perkembangan pertumbuhan ekonomi serta merupakan sebuah solusi sebagaimana yang telah diuraikan sebelumnya dan sebagian ahli pula menyatakan bahwa tak satupun manfaat yang dapat diperoleh oleh suatu negara yang preferensi penduduknya tidak dapat diakomodasi oleh anggaran pemerintahan, dan sistem kelembagaan pemerintah daerah yang jelek. Sebenarnya landasan teoritis yang menyokong mengenai peranan antara desentralisasi fiskal terhadap pertumbuhan ekonomi sampai saat ini terus dikembangkan dan permasalahan ini tetap menjadi topik perdebatan yang hangat diantara para ahli ekonomi. Bagaimanakah sebenarnya desentralisasi fiskal tersebut 
mempengaruhi pertumbuhan ekonomi, apakah secara langsung atau tidak langsung, hal inilah yang terus diuji secara teoritik mauapun empirik oleh para pakar ekonomi. Adanya argumnetasi yang menyatakan efek desentralisasi fiskal terhadap pertumbuhan ekonomi melalui efisiensi ekonomi, distribusi sumber daya regional dan stabilitas makro ekonomi pun tetap dipertanyakan karena terdapat banyak literatur empirik yang memberikan hasil yang berbeda di dalam penelitiannya (Vazquez dan McNab, 2001).

Otonomi daerah tidak mencakup bidang-bidang tertentu, seperti politik luar negeri, pertahanan keamanan, peradilan, moneter, fiskal, dan agama. Bidang-bidang tersebut tetap menjadi urusan pemerintah pusat. Pelaksanaan otonomi daerah berdasar pada prinsip demokrasi, keadilan, pemerataan, dan keanekaragaman.

Otonomi daerah adalah kewenangan daerah otonom untuk mengatur dan mengurus kepentingan masyarakat setempat menurut prakarsa sendiri berdasarkan aspirasi masyarakat sesuai dengan peraturan perundangundangan (pasal 1 huruf (h) UU Nomor 22 Tahun 1999 tentang Pemerintahan Daerah).

Daerah otonom, selanjutnya disebut daerah, adalah kesatuan masyarakat hukum yang mempunyai batas daerah tertentu berwenang, mengatur dan mengurus kepentingan masyarakat setempat menurut prakarsa sendiri berdasarkan aspirasi masyarakat dalam ikatan Negara 
Kesatuan Republik Indonesia (pasal 1 huruf (i) UU Nomor 22 Tahun 1999 tentang Pemerintahan Daerah).

\section{Dasar Hukum}

Otonomi daerah berpijak pada dasar Perundangan-undangan yang kuat, yakni:

1. Undang-undang Dasar

Sebagaimana telah disebut di atas Undang-undang Dasar 1945 merupakan landasan yang kuat untuk menyelenggarakan Otonomi Daerah. Pasal 18 UUD menyebutkan adanya pembagian pengelolaan pemerintahan pusat dan daerah.

2. Ketetapan MPR-RI Tap MPR-RI No. XV/MPR/1998 tentang penyelenggaraan otonomi daerah: Pengaturan, pembagian dan pemenfaatan sumber daya manusia nasional yang berkeadilan, serta perimbangan keuangan Pusat dan Daerah dalam kerangka NKRI.

3. Undang-undang No. 22/1999 tentang Pemerintahan Daerah pada prinsipnya mengatur penyelenggaraan Pemerintahan Daerah yang lebih mengutamakan pelaksanaan asas desentralisasi. Hal-hal yang mendasar dalam UU No. 22/1999 adalah mendorong untuk pemberdayaan masyarakat, menumbuhkan prakarsa dan kreativitas, meningkatkan peran masyarakat, mengembangkan peran dan fungsi DPRD.

Dari ketiga dasar perundangan-undangan tersebut di atas tidak diragukan lagi bahwa pelaksanaan otonomi daerah memiliki dasar hukum yang kuat. 
Tinggal permasalahannya adalah bagaimana dengan dasar hukum yang kuat tersebut pelaksanaan Otonomi Daerah bisa dijalankan secara optimal.

\section{Pokok-Pokok Pikiran Otonomi Daerah}

Isi dan jiwa yang terkandung dalam pasal 18 UUD 1945 beserta penjelasannya menjadi pedoman dalam penyusunan UU No.22/1999 dengan pokok-pokok pikiran sebagai berikut:

1. Sistem ketatanegaraan Indonesia wajib menjalankan prinsip-prinsip pembagian kewenangan berdasarkan asas konsentrasi dan desentralisasi dalam kerangka NKRI;

2. Daerah yang dibentuk berdasarkan asas desentralisasi dan dekonsetrasi adalah daerah provinsi, sedangkan daerah yang dibentuk berdasarkan asas desentralisasi adalah daerah kabupaten dan daerah kota. Daerah yang dibentuk dengan asas desentralisasi berwenang untuk menentukan dan melaksanakan kebijakan atas prakarsa sendiri berdasarkan aspirasi masyarakat;

3. Pembagian daerah diluar provinsi dibagi habis ke dalam daerah otonom. Dengan demikian, wilayah administrasi yang berada dalam daerah kabupaten dan daerah kota dapat dijadikan daerah otonom atau dihapus;

4. Kecamatan yang menurut UU No. 5 THN 1974 sebagai wilayah administrasi dalam rangka dekonsentrasi, menurut UU No.22/1999 kedudukannya diubah menjadi perangkat daerah kabupaten atau daerah kota. 


\section{Prinsip-Prinsip Pelaksanaan Otonomi Daerah}

Berdasar pada UU No. 22/1999 Prinsip-prinsip pelaksanaan Otonomi Daerah adalah sebagai berikut:

1. Penyelenggaraan Otonomi Daerah dilaksanakan dengan memperhatikan aspek-aspek demokrasi, keadilan, pemerataan, serta potensi, dan keanekaragaman daerah;

2. Pelaksanaan Otonomi Daearah didasarkan pada otonomi luas, nyata dan bertanggung jawa;

3. Pelaksanaan Otonomi Daerah yang luas dan utuh diletakkan pada daerah kabupaten dan daerah kota, sedang otonomi daerah provinsi merupakan otonomi terbatas;

4. Pelaksanaan otonomi daerah harus sesuai dengan konstitusi negara sehingga tetap terjamin hubungan yang serasi antara pusat dan daerah serta antar daerah;

5. Pelaksanaan otonomi daerah harus lebih meningkatkan kemandirian daerah otonom, dan karenanya dalam daerah kabupaten dan daerah kota tidak ada lagi wilayah administrasi;

6. Kawasan khusus yang dibina oleh Pemerintah atau pihak lain seperti Badan Otorita, Kawasan Pelabuhan, Kawasan Pertambangan, Kawasan Kehutanan, Kawasan Perkotaan Baru, Kawasan Wisata, dan semacamnya berlaku ketentuan peraturan Daerah Otonom;

7. Pelaksanaan Otonomi Daerah harus lebih meningkatkan peranan dan fungsi badan legislatif daerah, baik sebagai fungsi legislasi, fungsi 
pengawas maupun fungsi anggaran atas penyelenggaraan Pemerintahan Daerah;

8. Pelaksanaan asas dekonsentrasi diletakkan pada daerah Provinsi dalam kedudukannya sebagai wilayah administrasi untuk melaksanakan kewenangan pemerintah tertentu yang dilimpahkan kepada Gubernur sebagai wakil pemerintah.

\section{Perkembangan Otonomi Daerah di Indonesia}

Meskipun UUD 1945 yang menjadi acuan konstitusi telah menetapkan konsep dasar tentang kebijakan otonomi kepada daerah-daerah, tetapi dalam perkembangan sejarahnya ide otonomi daerah itu mengalami berbagai perubahan bentuk kebijakan yang disebabkan oleh kuatnya tarikmenarik kalangan elit politik pada masanya. Apabila perkembangan otonomi daerah dianalisis sejak tahun 1945, akan terlihat bahwa perubahan-perubahan konsepsi otonomi banyak ditentukan oleh para elit politik yang berkuasa pada saat itu. Hal itu terlihat jelas dalam aturanaturan mengenai pemerintahan daerah sebagaimana yang terdapat dalam UU berikut ini:

1. UU No.1/1945

Kebijakan Otonomi Daerah pada masa ini lebih menitikberatkan pada dekonsetrasi. Kepala daerah hanyalah kepanjangan tangan pemerintahan pusat. 
2. UU No. $22 / 1948$

Mulai tahun kebijakan otonomi daerah lebih menitikberatkan pada desentralisasi. Tetapi masih ada dualisme peran di kepala daerah, di satu sisi ia punya peran besar untuk daerah, tapi juga masih menjadi alat pemerintahan pusat.

3. UU No.1/1957

Kebijakan otonomi daerah pada masa ini maasih bersifat dualisme, dimana kepala daerah bertanggung jawab penuh pada DPRD, tetapi juga masih alat pemerintah pusat.

4. Penetapan Presiden No.6/1959

Pada masa ini kebijakan otonomi daerah lebih menekankan dekonsetrasi. Melalui Penpres ini kepala daerah diangkat oleh pemerintah pusat terutama dari kalangan pamong praja

\section{Perkembangan Agribisnis Dalam Pembangunan Ekonomi Daerah}

Dengan diluncurkannya UU No.22/1999 tentang otonomi daerah, telah terjadi perubahan yang mendasar dalam pembangunan nasional termasuk pembangunan ekonomi, ungkap Prof. Dr. Ir. Bungaran Saragih, M.Ec., Menteri Pertanian periode 2000-2004, saat diwawancarai AGRINA.

Sebelumnya, pengelolaan pembangunan ekonomi bersifat sentralistis dan lebih mengandalkan industri-industri besar berbasis impor. Yang akan datang pengelolaan pembangunan ekonomi berubah menjadi desentralisasi dan mengandalkan industri-idustri yang berbasis pada sumberdaya lokal. 
Hal ini berarti pembangunan ekonomi nasional akan terjadi pada setiap daerah dan perekonomian daerah inilah tulang punggung perekonomian Indonesia.

Keberhasilan pembangunan ekonomi daerah merupakan salah satu takaran bagi keberhasilan otonomi daerah. Sayangnya, paling tidak sampai saat ini masyarakat termasuk pemerintah lebih tertarik pada soal-soal pembagian keuangan antara pemerintah pusat dengan pemerintah daerah, dan sangat sedikit perhatian tentang membangunan ekonomi daerah. Tidak terlalu berlebihan bahwa paling tidak untuk beberapa dekade ke depan, jika kita berketetapan hati untuk membangun ekonomi daerah, maka tidak ada pilihan lain kecuali membangun sistem agribisnis yang berbasis pada sumberdaya lokal. Hal ini disebabkan sampai saat ini hampir seluruh ekonomi daerah di Indonesia berbasis pada sistem agribisnis baik dilihat dari pendapatan domestik regional bruto (PDRB), penyerapan tenaga kerja, penguasaan teknologi, maupun struktur ekspor. Karena itu, strategi pembangunan ekonomi daerah yang paling tepat dan efektif adalah melalui pembangunan sistem agribisnis.

\section{Kesimpulan}

1. Pembangunan ekonomi masa lalu telah menimbulkan kesenjangan ekonomi antar daerah semakin melebar. Kosentrasi idustrialisasi di beberapa daerah di pulau jawa ternyata tidak mampu menarik/menghela (driven) ekonomi daerah-daerah lain (sebagai periphery) ke arah yang 
lebih maju. Bahkan membuat kesenjangan ekonomi antar daerah semakin melebar.

2. Perubahan struktur ekonomi nasional pada masa lalu tidak mengakar pada perekonomian daerah, terutama daerah-daerah luar jawa. Ini berarti bahwa pertumbuhan ekonomi nasional sebagai buah dari perubahan struktur ekonomi nasional tidak dikonstribusikan secara optimal oleh perekonomian daerah.

3. Untuk meningkatkan peranan daerah terhadap pertumbuhan ekonomi nasional perlu ikhtiar yang sungguh-sungguh dan sistimatis melalui penerapan Strategi Agroindustri Berorientasi Ekspor di tingkat daerah dan Strategi Promosi Ekspor Berbasis Agribisnis di tingkat pusat.

\section{Referensi :}

Arsyad, L., 1999. Pengantar Perencanaan dan Pembangunan Ekonomi Daerah, Edisi Pertama. Yogyakarta: BPFE-Yogyakarta.

Adisasmita, H. R. 2005. Dasar-dasar Ekonomi Wilayah. Edisi Pertama. Yogyakarta: Penerbit Graha Ilmu. 


\title{
SISTEM DEMOKRASI SEKULER TAK MENDUKUNG PENDIDIKAN BERKARAKTER
}

\author{
ROMIATY
}

Prodi. Bimbingan dan Konseling FKIP - UNPAR

\begin{abstract}
Abstraksi : Kondisi remaja saat ini sangat memprihatinkan, degradasi moral seperti tawuran pelajar, seks bebas, aborsi, narkoba dan lain sebagainya seakan menjadi suguhan sehari-hari. Salah satu upaya yang dilakukan oleh para pakar pendidikan untuk menangani permasalahan tersebut adalah dengan pendidikan berkarakter. Pendidikan berkarakter adalah Pendidikan untuk pembangunan karakter yang mencakup pengembangan substansi, proses dan suasana atau lingkungan yang menggugah, mendorong, dan memudahkan seseorang untuk mengembangkan kebiasaan baik dalam kehidupan sehari-hari. Agar terwujud pendidikan yang berkarakter maka peran negara sangatlah penting. Kebijakankebijakan yang di terapkan oleh Negara haruslah mendukung pembentukkan karakter yang baik pada remaja. Akan tetapi pada kenyataannya dalam sistem demokrasi sekuler kebijakan-kebijakan yang diambil sarat dengan berbagai kepentingan. Beberapa kebijakan yang tidak mendukung pembentukkan karakter antara lain; dalam menyikapi tawuran remaja diatur dalam Pasal 170 KUHP. Pasal ini mengandung kendala dan kontroversial tanpa memberikan efek jera. UU No 8/1992 tentang Perfilman, UU No 36/1999 tentang Telekomunikasi, UU No 40/1999 tentang Pers dan UU No 32/2002 tentang Penyiaran, yang mempermudah praktik seks bebas pada remaja dan RUU Kesetaraan dan Keadilan Gender (KKG) yang mempermudah praktik aborsi. Dan semua itu akan membuat pendidikan karakter di Indonesia hanya pada tataran teori dan sulit dalam pengaplikasiannya.
\end{abstract}

\section{Keywords : Sistem Demokrasi, Pendidikan Karakter}

Dunia pendidikan tercoreng kembali, korban tawuran antar pelajar dari tahun ke tahun mengalami peningkatan. Hal ini menambah deretan kasus panjang di dunia pendidikan Indonesia. Berbagai kajian ilmiah telah dilakukan oleh para pakar pendidikan untuk mencari solusi yang tepat bagi permasalahan dunia pendidikan. Tidak hanya tawuran antar pelajar, seks bebas, pengkonsumsi pornografi, aborsi, narkoba dan masih banyak lagi. 
Di zaman informasi dan teknologi saat ini, memudahkan untuk mengakses informasi tanpa filter. Maraknya suguhan informasi dari media cetak dan elektronik yang berisi pornografi juga turut memperburuk kondisi psikologis anak-anak bangsa.

Bagi sebuah bangsa dan Negara, anak adalah asset penting bagi kelangsungan suatu bangsa. Rusaknya perkembangan berpikir, emosional dan spiritualitas mereka saat ini akan membuat kerusakan pada suatu bangsa di masa yang akan datang. Penerus kepemimpinan yang akan mengayomi masyarakat akan semakin sulit untuk dicapai.

Berikut adalah data-data kerusakan remaja yang terjadi di Indonesia.

1. Data Komnas PA merilis jumlah tawuran pelajar tahun ini sebanyak 339 kasus dan memakan korban jiwa 82 orang. Tahun sebelumnya, jumlah tawuran antar-pelajar sebanyak 128 kasus.

Tak berbeda jauh, data dari Komisi Perlindungan Anak Indonesia (KPAI) menyebutkan, pengaduan kekerasan kepada anak sebanyak 107 kasus, dengan bentuk kekerasan seperti kekerasan fisik, kekerasan psikis, pembunuhan, dan penganiayaan. ${ }^{5}$

2. Zoy Amirin, pakar psikologi seksual dari Universitas Indonesia mengutip Sexual Behavior Survey 2011 yang menunjukkan 64 persen anak muda di kota-kota besar Indonesia 'belajar' seks melalui film porno atau DVD bajakan. Akibatnya, 39 persen responden ABG usia 15-19 tahun sudah pernah berhubungan seksual, sisanya 61 persen berusia 20-25 tahun.

\footnotetext{
${ }^{5}$ http://ads3.kompasads.com/new diunduh 26/9/2012
} 
Survei yang didukung pabrik kondom Fiesta itu mewawancari 663 responden berusia 15-25 tahun tentang perilaku seksnya di Jabodetabek, Bandung, Yogyakarta, Surabaya dan Bali pada bulan Mei $2011 .^{6}$

3. Remaja puteri dikota-kota besar cenderung sudah tidak perawan. Hal ini berdasarkan hasil survei dari BKKBN yang menyatakan bahwa separuh dari perempuan lajang dikota besar khususnya Jabotabek kehilangan keperawanan dan melakukan hubungan seks pranikah. Tak sedikit pula yang hamil diluar nikah. Rentang usia yang melakukan seks pranikah $\begin{array}{llllll}\text { berkisar } & \text { antara } & 13 & - & 18 & \text { tahun. }\end{array}$ Diwilayah lain di Indonesia seperti Surabaya perempuan lajang yang sudah kehilangan keperawanan mencapai $54 \%$, Bandung $47 \%$, dan Medan $52 \%$. Data ini dikumpulkan BKKBN sepanjang kurun waktu tahun 2010. Senada dengan pernyataan Kepala BKKBN, Bpk. Sugiri Syarif "berdasarkan data yang kami himpun dari 100 orang remaja, 51 diantaranya sudah tidak lagi perawan". ${ }^{7}$

4. Berdasarkan data yang dikeluarkan $\mathrm{BKKBN}$, diperkirakan setiap tahun jumlah aborsi di Indonesia mencapai 2,4 juta jiwa. Bahkan, 800 ribu di antaranya terjadi di kalangan remaja.

(Komnas PA) pada 2011 ada sekitar 2 juta tindak aborsi yang dilakukan pada tahun 2008. Dari jumlah tersebut, sekitar 62 persen lebih dilakukan oleh remaja. ${ }^{8}$

\footnotetext{
${ }^{6}$ www.kepri.bkkbn.go.id diunduh pada tanggal 26/9/2012

7 www.jurnas.com/news diunduh pada tanggal 26/9/2012

${ }^{8}$ www.bkkbn.go.id diunduh pada tanggal 26/9/2012
} 
5. Anak-anak sudah banyak yang terlibat narkoba. Jumlah pecandu narkoba di Indonesia pada 2008 mencapai 3,6 juta orang. Rata-rata berada pada usia prodiktif 12 - 24 tahun. Di antara mereka yang telah mencoba narkoba, 80 persen menggunakannya di rumah sendiri dan 20 persen di rumah teman. Berdasarkan riset 100 persen pecandu narkoba adalah perokok dan juga mengkonsumsi alcohol. $^{9}$

\section{Pendidikan Karakter sebagai sebuah Alternatif Solusi}

Berbagai kajian ilmiah yang dilakukan oleh pakar pendidikan telah mencoba untuk memberikan alternatif solusi salah satunya adalah pendidikan karakter.

Pendidikan Karakter merupakan "keseluruhan disposisi kodrati dan disposisi yang telah dikuasai secara stabil yang mendefinisikan seorang individu dalam keseluruhan tata perilaku psikisnya yang menjadikannya tipikal dalam cara berpikir dan bertindak . Karakter dapat dipetakan dalam dua aspek penting dalam diri individu, yaitu kesatuan (cara bertindak yang koheren) dan stabilitas (kesatuan berkesinambungan dalam kurun waktu), karena itu ada proses strukturisasi psikologis dalam diri individu yang secara kodrati sifatnya reaktif terhadap lingkungan. Beberapa kriteria karakter seperti halnya: stabilitas pola perilaku, kesinambungan dalam waktu, koherensi cara berpikir dalam bertindak. Hal tersebut telah menarik perhatian serius para pendidik dan pakar ilmu pendidikan untuk memikirkannya dalam kerangka proses pendidikan karakter.

\footnotetext{
${ }^{9}$ www.bkkbn.go.id didunduh pada tanggal 26/9/2012
} 
Dengan demikian, pendidikan karakter merupakan dinamika pengembangan kemampuan yang berkesinambungan dalam diri manusia untuk mengadakan internalisasi nilai-nilai sehingga menghasilkan disposisi aktif, stabil dalam diri individu. Dinamika ini membuat pertumbuhan individu menjadi semakin utuh. Unsur-unsur ini menjadi dimensi yang menjiwai proses formasi setiap inividu. Jadi, karakter merupakan sebuah kondisi dinamis struktur antropologis individu yang tidak hanya sekedar berhenti atas determininasi kodratinya, melainkan sebuah usaha aktif untuk menjadi semakin integral mengatasi determinasi alam dalam dirinya semakin proses penyempurnaan dirinya (Koesoema, 2004:104). ${ }^{10}$

Pendidikan untuk pembangunan karakter pada dasarnya mencakup pengembangan substansi, proses dan suasana atau lingkungan yang menggugah, mendorong, dan memudahkan seseorang untuk mengembangkan kebiasaan baik dalam kehidupan sehari-hari. Kebiasaan ini timbul dan berkembang dengan didasari oleh kesadaran, keyakinan, kepekaan, dan sikap orang yang bersangkutan. Dengan demikian, karakter bersifat inside-out, dalam arti bahwa perilaku yang berkembang menjadi kebiasaan baik ini terjadi karena adanya dorongan dari dalam, bukan karena adanya paksaan dari luar (Raka,2007:6). ${ }^{6}$

Proses pembangunan karakter pada seseorang dipengaruhi oleh faktorfaktor khas yang ada pada orang yang bersangkutan yang sering juga disebut faktor bawaan (nature) dan lingkungan (nurture) di mana orang yang bersangkutan tumbuh dan berkembang. Namun demikian, perlu diingat bahwa faktor bawaan boleh dikatakan berada di luar jangkauan masyarakat untuk

\footnotetext{
${ }^{10}$ Siti Irene Astuti. D.,Dr, Laporan Penelitian implementasi Pendidikan KArakter ISBD,2010 http://staf.uny.ac.id/sites/default/penelitian
} 
mempengaruhinya. Hal yang berada dalam pengaruh kita, sebagai individu maupun bagian dari masyarakat, adalah faktor lingkungan. Jadi, dalam usaha pengembangan atau pembangunan karakter pada tataran individu dan masyarakat, fokus perhatian kita adalah pada faktor yang bisa kita pengaruhi atau lingkungan, yaitu pada pembentukan lingkungan. Dalam pembentukan lingkungan inilah peran lingkungan pendidikan menjadi sangat penting, bahkan sangat sentral, karena pada dasarnya karakter adalah kualitas pribadi seseorang yang terbentuk melalui proses belajar,baik belajar secara formal maupun informal (Raka,2007:7).

Karakter merupakan ciri dasar melalui mana pribadi itu terarah ke depan dalam membentuk dirinya secara penuh sebagai manusia apapun pengalaman psikologi yang dimilikinya. Dalam hal ini, pengembangan karakter merupakan proses yang terjadi secara terus-menerus, karakter bukan kenyataan melainkan keutuhan perilaku. Karakter bukanlah hasil atau produk melainkan usaha hidup. Usaha ini akan semakin efektif, ketika manusia melakukan apa yang menjadi kemampuan yang dimiliki oleh individu (Koesoema,2004:103). ${ }^{6}$

\section{Pendidikan Karakter Bukan Hanya Tanggung Jawab Sekolah}

Penekanan pendidikan karakter saat ini dititikberatkan pada peran sekolah sebagai suatu institusi formal yang berfungsi untuk membina dan mendidik siswa agar tidak hanya memiliki kemampuan ilmu pengetahuan dan teknologi (IPTEK) tetapi juga menjadi manusia yang beriman dan bertakwa (IMTAK). Di sekolah, guru adalah figur yang diharapkan mampu mendidik anak yang berkarakter, berbudaya, dan bermoral. Guru merupakan teladan bagi siswa dan memiliki peran yang sangat besar dalam pembentukan karakter siswa. Peran pendidik sebagai 
pembentuk generasi muda yang berkarakter sesuai UU Guru dan Dosen, UU No. 14 tahun 2005, guru didefinisikan sebagai pendidik profesional dengan tugas utama mendidik, mengajar, membimbing, mengarahkan, melatih, menilai, dan mengevaluasi peserta didik pada pendidikan anak usia dini jalur pendidikan formal, pendidikan dasar, dan pendidikan menengah.

Berbagai program mulai diterapkan disekolah, mulai dari peningkatan performa mengajar guru meliputi aspek kemampuan kognitif, keterampilan profesional dan keterampilan sosial (Slavin :1994), meningkatkan kesesuaian dan mutu pendidikan karakter yang dikembangkan oleh Kementerian Pendidikan Nasional. Kementerian Pendidikan Nasional mengembangkan grand design pendidikan karakter untuk setiap jalur, jenjang, dan jenis satuan pendidikan. Grand design menjadi rujukan konseptual dan operasional pengembangan, pelaksanaan, dan penilaian pada setiap jalur dan jenjang pendidikan. Konfigurasi karakter dalam konteks totalitas proses psikologis dan sosial-kultural tersebut dikelompokan dalam: Olah Hati (Spiritual and emotional development), Olah Pikir (intellectual development), Olah Raga dan Kinestetik (Physical and kinestetic development), dan Olah Rasa dan Karsa (Affective and Creativity development). Pengembangan dan implementasi pendidikan karakter perlu dilakukan dengan mengacu pada grand design tersebut. ${ }^{11}$

Akan tetapi pada kenyataannya beban berat dalam membentuk karakter siswa tidak dapat dilakukan oleh sekolah saja. Banyaknya tugas-tugas belajar

\footnotetext{
${ }^{11}$ Amin-x, contoh Makalah Pendidikan Karakter,2012 http://amin-x.blogspot.com/2012/07/contoh-makalah-pendidikan-karakter.html
} 
disekolah, kurangnya jam pelajaran agama, tingginya persaingan belajar antar siswa. Kondisi seperti ini tentu hanya akan melahirkan siswa yang ahli dalam ilmu pengetahuan dan teknologi saja tetapi miskin dalam iman dan takwa. Padahal iman dan takwa adalah modal penting dalam pembentukkan karakter siswa. Di tambah lagi, siswa mengikuti pendidikan di sekolah hanya sekitar 7 jam per hari, atau kurang dari $30 \%$. Selebihnya (70\%), peserta didik berada dalam keluarga dan lingkungan sekitarnya. Jika dilihat dari aspek kuantitas waktu, pendidikan di sekolah berkontribusi hanya sebesar $30 \%$ terhadap hasil pendidikan peserta didik. Hal ini menunjukkan bahwa faktor keluarga dan lingkungan sebagai pendidikan informal siswa justu memberikan kontribusi yang sangat penting bagi terbentuknya karakter siswa $(70 \%)^{7}$

Walaupun keluarga dan lingkungan memberikan konstribusi yang signifikan dalam membentuk karakter siswa, akan tetapi pada kenyataannya permasalahan yang muncul di dunia pendidikan tidak kunjung terselesaikan. Kasus-kasus kenakalan remaja semakin meningkat dari tahun ke tahun. Lalu apa yang menjadi akar permasalahannya?

\section{Sistem Demokrasi Sekuler sebagai Akar Permasalahan}

Sebab mendasar dari semua kebobrokan itu adalah diterapkannya sistem demokrasi sekuler. Salah satu esensi mendasar demokrasi adalah kedaulatan menjadi milik rakyat. Dalam ungkapan lain, menurut International Commision of Jurist dalam konferensinya di Bangkok, perumusan yang paling umum mengenai sistem politik demokratis adalah suatu bentuk pemerintahan dimana hak untuk 
membuat keputusan politik diselenggarakan oleh warga negara melalui wakilwakil yang dipilih oleh mereka dan yang bertanggung jawab kepada mereka melalui suatu proses pemilihan yang bebas (Budiardjo,2008). Namun demikian, itu baru dalam tataran teori. Dalam tataran praktiknya tidaklah demikian. Dalam Negara demokrasi, yang sering berlaku adalah hukum besi oligarki, yaitu sekelompok penguasa saling bekerja sama untuk menentukan kebijakan politik sosial dan ekonomi Negara tanpa harus menanyakan bagaimana aspirasi rakyat yang sebenarnya. ${ }^{12}$

Akhirnya tidak ada standar baku tentang benar salah. Semuanya dikembalikan kepada manusia dan kesepakatan diantara manusia. Disitulah lahir peraturan-peraturan yang sarat dengan kepentingan. Disamping, peraturan itu sendiri tidak baku bisa berubah mengikuti kehendak (wakil) rakyat. Sehingga aturan yang menjadi standar penyelesaian suatu masalah, tidaklah menyelesaikan masalah yang ada bahkan menambah masalah baru yang semakin tak terselesaikan.

Karena pemilik kedaulatan adalah manusia maka manusia memiliki kebebasan dalam segala hal. Pemahaman seperti ini juga telah mewarnai dalam kehidupan sosial kemasyarkatan. Paham kebebasan (liberalisme) yang menjadi salah satu pilar sistem sekuler demokrasi menjadikan pengaturan urusan manusia harus menjamin kebebasan manusia. Kebebasan itu tidak boleh dilanggar dan harus dijamin keberadaan dan pengekspresiannya. Sehingga peraturan dan

\footnotetext{
${ }^{12}$ Farid Wadjidi,Shiddiq Al-Jawi et.al. Ilusi Negara Demokrasi,2009, Al-Azhar Press, Bogor
} 
kebijakan politik yang dikeluarkan tidak boleh melanggar kebebasan ini. Lahirlah peraturan dan kebijakan yang bersifat permisif.

Selain itu dalam sistem sekuler demokrasi, aturan akhirnya menjadi semacam solusi kompromi atas persoalan yang ada dengan tetap menjamin kebebasan dasar yang dimiliki setiap orang (kebebasan berkeyakinan, berpendapat, berperilaku dan kepemilikan). Maka lahirlah peraturan yang menjamin dan memperbolehkan semua ekspresi kebebasan dengan batasan asal tidak melanggar kebebasan orang lain dan asal tidak mengganggu kepentingan umum. Dalam sistem sekuler demokrasi seperti ini, setiap orang boleh mengekspresikan hasrat seksualnya dengan siapa pun dengan cara apa pun selama suka sama suka dan tidak merugikan pihak lain. Dan itulah yang dilegalkan dalam sistem hukum yang ada. ${ }^{13}$

Permasalahan yang terjadi pada siswa saat ini juga tidak terlepas dari kebijakan-kebijakan yang di keluarkan oleh pemerintah yang menerapkan sistem kapitalisme. Dalam menyikapi tawuran remaja yang memakan korban, diatur dalam Pasal 170 KUHP. Pasal ini berbunyi, ”Barang siapa terang-terangan dan dengan tenaga bersama menggunakan kekerasan terhadap orang atau barang diancam dengan pidana penjara paling lama lima tahun enam bulan”. Pasal ini mengandung kendala dan kontroversial. Subyek "barang siapa" menunjuk pelaku satu orang. Sementara istilah "dengan tenaga bersama" mengindikasikan suatu

\footnotetext{
13 Hizbut Tahrir Indonesia, media Al-Islam edisi 617, Penerapan Syariah Islam Selamatkan Remaja dari Kenakalan dan Kriminalitas, 2012
} 
kelompok manusia. Delik itu, menurut penjelasannya, tak ditujukan pada kelompok yang tak turut melakukan kekerasan. Ancaman hanya ditujukan kepada yang benar-benar terbuka dan dengan tenaga bersama melakukan tawuran. Mengingat suatu kelompok massa, khususnya pelajar unik sifatnya, delik Pasal 170 sukar diterapkan karena banyak pelaku tawuran sebenarnya terlibat secara tak sengaja atau hanya ikut-ikutan dalam kerumunan.(kompas.com kompleksitas tawuran pelajar)Sehingga banyak siswa yang terjaring ketika melakukan tawuran hanya mendapat sangsi saja kemudian diberikan pengarahan lalu dibebaskan. ${ }^{14}$

Untuk mengatasi permasalahan seks bebas pada siswa Negara juga seolah menutup mata. Media cetak, media elektronik dan internet dibiarkan secara bebas untuk menyajikan pornografi. American Demographics Magazine dalam laporannya menyatakan bahwa jumlah situs pornografi meningkat dari 22.100 pada tahun 1997 menjadi 280.300 pada tahun 2000 atau melonjak 10 kali lebih dalam kurun waktu tiga tahun. Apabila dirata-rata, berarti setiap hari muncul 200an lebih situs porno baru dan bisa dibayangkan berapa jumlahnya saat ini. Sementara Nathan Tabor, dalam artikelnya yang berjudul Adultary is killing the American Family mengatakan bahwa statistik menunjukkan bahwa $25 \%$ dari semua internet, mesin pencarinya minta dihubungkan dengan pornografi. ${ }^{15}$

Larangan pornografi sebenarnya telah diatur dalam hukum positif di Indonesia, diantaranya adalah dalam KUHP, UU No 8/1992 tentang Perfilman, UU No 36/1999 tentang Telekomunikasi, UU No 40/1999 tentang Pers dan UU No 32/2002 tentang Penyiaran. Namun pada tahap aplikasi, beberapa UU ini tidak

\footnotetext{
${ }^{14}$ Kompleksitas tawuran, www.kompas.com diunduh pada tanggal 26/9/2012

${ }^{15}$ Dwi Haryadi, S.H.,M.H.,Internet:Media Pendidikan atau Media Pornografi, http://www.ubb.ac.id/
} 
dapat bekerja dengan maksimal karena mengandung beberapa kelemahan dan kekurangan pada substansinya, yaitu perumusan melanggar kesusilaan yang bersifat abstrak/multitafsir, jurisdiksi yang bersifat territorial dan perumusan beberapa istilah dan pengertiannya yang tidak mencakup aktivitas pornografi di internet, sistem perumusan sanksi pidana yang tidak tepat dan jumlah sanksi pidana denda yang relatif kecil, sistem perumusan pertanggungjawaban pidana korporasi/badan hukum yang tidak jelas dan tidak rinci, dan tidak adanya harmonisasi tindak pidana dan kebijakan formulasi tindak pidana, baik pada tingkat nasional, regional maupun internasional. Adanya kelemahan-kelemahan ini menunjukkan perlu adanya amandemen bahkan pembaharuan hukum, agar hukum dapat menjangkau penjahat-penjahat di dunia maya. ${ }^{11}$

Dalam mengatasi masalah perilaku seks bebas di kalangan remaja. Kampanye safe sex with condom gencar dilaksanakan. Menteri Kesehatan Nafsiah Mboi dengan program kondomisasi remaja, hal ini untuk menekan penyebaran HIV/AIDS dikalangan remaja. Bertentangan dengan pendapat seorang pakar AIDS, R. Smith (1995) setelah bertahun-tahunmengikuti ancaman AIDS dan penggunaan kondom mengecam mereka yang telah menyebarkan safe sex dengan cara menggunakan kondom sebagai "sama saja dengan mengundang kematian”. Beliau juga berpendapat agar resiko penularan/penyebaran HIV/AIDS diberantas dengan cara menghindari hubungan seksual di luar nikah.

Kondomisasi bukan menghilangkan penyebaran HIV/AIDS tetapi secara tidak langsung melegalkan seks bebas. Hal ini pernah diungkapkan oleh Mark 
Schuster dari Rand, sebuah penelitian nirlaba dan seorang pediatric di University of California. Berdasarkan penelitian mereka, setelah kampanye kondomisasi, aktifitas seks bebas dikalangan pelajar pria meningkat dari $37 \%$ menjadi $50 \%$ dan dikalangan pelajar wanita meningkat dari $27 \%$ menjadi $32 \% .^{16}$

Praktik seks bebas yang dilakukan oleh remaja beresiko munculnya kehamilan yang tidak diinginkan dikalangan siswa. Untuk mengatasi kehamilan yang tidak diinginkan banyak siswi yang akhirnya melakukan tindakan aborsi. Ditambah lagi adanya RUU Kesetaraan dan Keadilan Gender (KKG) yang mempermudah praktik aborsi. Seperti yang tercantum pada Pasal 9 ayat (1) menyatakan kesempatan yang sama dan perlakuan yang adil dalam pemenuhan hak kesehatan reproduksi, hak pendidikan, hak ekonomi dan ketenagakerjaan, keterwakilan perempuan, perkawinan dan hubungan keluarga. Perempuan/remaja perempuan harus dijamin mendapatkan informasi dan pelayanan kesehatan seksual dan reproduksi, termasuk kemudahan mendapatkan kontrasepsi untuk mengurangi tingkat aborsi tidak aman dan kehamilan. ${ }^{17}$

Kasus-kasus aborsi yang direkam Komisi Nasional Perlindungan Anak Indonesia (KPAI) membuat kita miris. Kasus aborsi mulai 2008 hingga 2010 terus meningkat. Ironisnya, 62 persen pelakunya melibatkan anak-anak di bawah umur. Diperkirakan selama kurun waktu tersebut, kenaikan angka kasus aborsi rata-rata 15 persen setiap tahunnya. Pada 2008 ditemukan ada 2 juta jiwa anak

\footnotetext{
${ }^{16}$ Al-wai'e, Media Politik dan Dakwah,No.147 tahun XIII

${ }^{17}$ Hizbut Tahrir Indonesia, Buletin Dakwah Al-Islam edisi 602, RUU KKG bertentangan dengan Islam, Berbahaya dan Merusak, 2012
} 
korban aborsi. Tahun berikutnya, anak korban aborsi bertambah 300 ribu jiwa. Pada 2010, bertambah lagi 200 ribu jiwa.

Kasus aborsi semakin mencolok di kota-kota besar. Yang paling mencengangkan adalah lebih dari separuh pelaku aborsi adalah anak di bawah umur. Anak-anak ini baru berumur kurang dari 18 tahun. Praktik aborsi yang paling dominan, dilakukan 37 persen pelakunya adalah dengan cara kuret atau pembersihan rahim, 25 persen melalui oral dengan meminum pil tertentu dan pijatan, 13 persen dengan cara suntik, dan 8 persen dengan cara memasukkan benda asing ke dalam rahim. Selain itu juga ada cara jamu dan akupuntur. ${ }^{18}$

\section{Penutup}

Pendidikan berkarakter akan tetap berjalan di tempat tanpa adanya dukungan dari Negara. Sistem demokrasi sekuler yang diusung oleh Indonesia saat ini memperburuk kondisi anak. Permasalahan-permasalahan yang ada tidak terselesaikan dan permasalahan baru akan segera bermunculan. Sebaik apapun program pendidikan yang dilaksanakan tanpa adanya kesinambungan dengan kebijakan pemerintah maka semua akan sia-sia. Hal ini menunjukkan bahwa sistem demokrasi sekuler tidak mendukung pembentukkan karakter pada siswa.

\section{Referensi}

Amin-x, contoh Makalah Pendidikan Karakter,2012

http://amin-x.blogspot.com/2012/07/contoh-makalah-pendidikan-

\footnotetext{
${ }^{18}$ DPD Hizbut Tahrir Indonesia Kalimantan Tengah, Mewaspadai Upaya Liberalisasi di balik Amandemen UU No.23/1992 tentang Kesehatan, 2005,Hizbut Tahrir Indonesia Kalimantan Tengah, Palangkaraya.
} 
karakter.html

Al-wai’e, Media Politik dan Dakwah,No.147 tahun XIII

DPD Hizbut Tahrir Indonesia Kalimantan Tengah, Mewaspadai Upaya Liberalisasi

di balik Amandemen UU No.23/1992 tentang Kesehatan, 2005, Hizbut Tahrir Indonesia Kalimantan Tengah, Palangkaraya.

Dwi Haryadi, S.H.,M.H.,Internet:Media Pendidikan atau Media Pornografi, http://www.ubb.ac.id/

Farid Wadjidi,Shiddiq Al-Jawi et.al. Ilusi Negara Demokrasi,2009, Al-Azhar Press, Bogor

Hizbut Tahrir Indonesia, media Al-Islam edisi 617, Penerapan Syariah Islam Selamatkan Remaja dari Kenakalan dan Kriminalitas, 2012

Hizbut Tahrir Indonesia, Buletin Dakwah Al-Islam edisi 602, RUU KKG

Bertentangan dengan Islam, Berbahaya dan Merusak, 2012

Siti Irene Astuti. D.,Dr, Laporan Penelitian implementasi Pendidikan Karakter ISBD,2010, http://staf.uny.ac.id/sites/default/penelitian

http://ads3.kompasads.com/new

www.kompas.com, Kompleksitas tawuran, diunduh pada tanggal 26/9/2012

www.kepri.bkkbn.go.id diunduh pada tanggal 26/9/2012

www.jurnas.com/news diunduh pada tanggal 26/9/2012

www.bkkbn.go.id diunduh pada tanggal 26/9/2012

www.bkkbn.go.id didunduh pada tanggal 26/9/2012 


\title{
PERANAN IBU DALAM PEMBINAAN KEPRIBADIAN ANAK \\ SOPHIA OKTAVIA BALIMULIA \\ FKIP - Universitas Palangkaraya
}

\begin{abstract}
The research was conducted with the aim to study the role of the mother in the child's personality development. Mother as the figure closest to the child have an interesting relationship dynamics with his son. The subjects were randomly selected mothers. This research method uses descriptive quantitative methods of data collection techniques by using questionnaires and interviews. The results is described descriptively. The conclusion can be drawn that the mother has been carrying out the role of the child's personality development quite well although it is still unknown mother's ability to master his feelings in the implementation of discipline in children still need to be reviewed and the persistence of giving labels in children's personality development to enable the child to be less than the maximum.
\end{abstract}

Keywords: Mother, Personality

\section{Pendahuluan}

Lapandi (2007) konteks asli dari kepribadian adalah gambaran eksternal dan sosial, hal ini diilustrasikan berdasarkan peran seseorang yang dimainkannya dalam masyarakat. Pada dasarnya manusialah yang menyerahkan sebuah kepribadian kepada masyarakatnya dan masyarakat akan menilainya sesuai dengan kepribadian tersebut. Kepribadian adalah ciri atau karakteristik atau gaya atau sifat khas dari diri seseorang yang bersumber dari bentukan-bentukan yang diterima dari lingkungan, keluarga pada masa kecil, dan juga bawaan orang sejak lahir (Sarkawi, 2008).

Ibu dipandang sebagai penentu utama dalam pembentukan kepribadian anak karena ibu merupakan kelompok sosial pertama yang menjadi pusat identifikasi anak. Ibu adalah pendidik pertama dan utama selain ayah, namun 
karena ibu merupakan individu yang paling dekat dengan anak mulai maka kelekatan pada ibu jauh lebih erat daripada dengan individu lain. Ibu bersama ayah memiliki tanggung jawab yang penuh dalam mendidik, mengasuh, dan membimbing anak-anaknya untuk mengembangkan kemampuan atau potensi dan karakter diri anak. Ibu sebagai figur yang lebih banyak menghabiskan waktu bersama dengan anak-anaknya di harapkan mampu melakukan pembinaan kepribadian pada diri anak sehingga anak mampu mengembangkan kepribadian yang diharapkan. Pembinaan kepribadian anak sejak dini sangat penting diberikan oleh ibu kepada anak karena pembinaan yang dilakukan oleh ibu akan sangat bermanfaat bagi pembentuk karakter diri anak. Oleh karena itu melalui penelitian ini peneliti ingin mengetahui peranan ibu dalam melaksanakan perananannya dalam pembinaan kepribadian anak.

\section{Peran ibu terhadap anak}

Pengertian orang tua diatas tidak terlepas dari pengertian keluarga bagian besar yang sebagian besar telah tergantikan oleh keluarga inti yang terdiri dari ayah, ibu dan anak-anak Arif (dalam Suliadi, 2011). Keluarga dipandang sebagai penentu utama dalam pembentukan kepribadian anak, alasannya adalah (1) keluarga merupakan kelompok sosial pertama yang menjadi pusat identifikasi anak, (2) anak banyak menghabiskan waktunya dilingkungan keluarga, dan (3) para anggota keluarga merupakan"significant people" bagi pembentukan kepribadian anak. Disamping itu keluarga juga dipandang sebagai lembaga yang 
dapat memenuhi kebutuhan insani(manusia), terutama bagi pengembangan ras manusia.

Ibu sebagai figur terdekat dengan anak, ia akan lebih banyak menghabiskan waktu bersama anak sehingga hubungan interpersonal antara ibu dan anak akan terjalin dengan erat (Sulivan, 1980). Jalinan kasih sayang antara ibu dan anak ini akan menbantu ibu untuk membantu anaknya dalam mengembangkan kepribadiannya. Menurut Sulivan (1980) hubungan ini dan anak pada masa kanak-kanak akan membantu anak dalam mengembangkan "selfsystem"nya atau pengembangan sistem diri anak yang berkaitan dengan struktur kepribadian anak.

\section{Pengertian Kepribadian}

Ali, dkk (Lapandi, 2007) mengatakan bahwa kata kepribadian berasal dari bahasa Italia dan inggris yang berarti persona atau personality yang berarti topeng. Akan tetapi sampai saat ini asal usul kata ini belum diketahui. Masih menurut Lapandi (2007) konteks asli dari kepribadian adalah gambaran eksternal dan sosial, hal ini diilustrasikan berdasarkan peran seseorang yang dimainkannya dalam masyarakat. Pada dasarnya manusialah yang menyerahkan sebuah kepribadian kepada masyarakatnya dan masyarakat akan menilainya sesuai dengan kepribadian tersebut. Menurut Browner (dalam Sjarkawi, 2008) kepribadian adalah corak tingkah laku sosial, corak ketakutan, dorongan dan keinginan, corak gerak gerik, opini dan sikap. Menurut Istiyono kepribadian adalah sifat yang dimiliki seseorang atau suatu bangsa (Kamus Pintar Bahasa 
Indonesia, 2006). Sedangkan menurut Inge (2007) kepribadian adalah tentang diri pribadi secara keseluruhan, kepribadian adalah sesuatu yang unik pada diri masing-masing individu. Gordon (dalam Salahudin, 2010) kepribadian adalah organisasi dinamis dalam diri individu sebagai sistem psikofisik yang menentukan cara yang unik dalam menyesuaikan diri dengan lingkungannya.

Definisi kepribadian memiliki lebih dari lima puluh arti akan tetapi definisi kepribadian yang penulis maksud disini adalah himpunan dan ciri-ciri jasmani dan rohani atau kejiwaan yang relatif tetap yang membedakan seseorang dengan orang lain pada sisi dan kondisi yang berbeda-beda.

Berdasarkan pengertian di atas, dapat simpulkan bahwa kepribadian mencakup berbagai aspek dan sifat-sifat fisik maupun psikis dari seorang individu yang menyebabkan individu berbuat dan bertindak seperti apa yang dia lakukan, dan menunjukkan adanya ciri-ciri yang khas yang membedakan individu itu dengan individu yang lain. Termasuk di dalamnya: sikapnya, nilai-nilai dan cita-citanya, pengetahuan, dan keterampilannya, macam-macam gerak tubuhnya dan sebagainya. Disamping itu, untuk menunjukkan terhadap individu seseorang yang berdiri sendiri terlepas dari individu yang lain, biasanya selalu dikaitkan dengan pola tingkah laku manusia yang berhubungan dengan norma-norma tentang baik dan buruk atau dengan kata lain, kata pribadi atau kepribadian dipakai untuk menunjukkan adanya ciri-ciri khas yang ada pada seseorang. 
Kepribadian mengandung pengertian yang kompleks terdiri dari bermacam-macam aspek, baik fisik maupun psikis. Abin syamsuddin ( dalam Salahudin 2010) mengemukakan aspek-aspek kepribadian sebagai berikut.

1. Karakter yaitu konsekuen tidaknya dalam mematuhi etika prilaku, konsekuen-tidaknya dalam memegang pendirian atau pendapat;

2. Temperamen yaitu disposisi reaktif seseorang atau cepat lambatnya reaksi terhadap rangsangan-rangsangan yang datang dari lingkungannya;

3. Sikap yaitu sambutan terhadap objek yang bersifat positif, negatif atau ambivalen;

4. Stabilitas emosi yaitu kadar kestabilan reaksi emosional terhadap rangsangan dari lingkungan;

5. Respontibilitas (tanggung jawab) yaitu kesiapan untuk menerima resiko dari tindakan atau perbuatan yang dilakukan;

6. Sosiabilitas yaitu disposisi pribadi yang berkaitan dengan hubungan interpersonal.

\section{Sikap Ibu Mendukung Pembentukan Kepribadian Anak}

Sikap ibu terhadap anak sangat mempengaruhi kepribadian anak. Sikap yang baik yang dapat mendukung pembentukan kepribadian anak menurut Junaidi (2010) antara lain:

1. Penanaman pekerti sejak dini

Ibu dan keluarga adalah penanggung jawab pertama dan utama penanaman sopan santun dan budi pekerti bagi anak. Baru kemudian proses penanaman akan dilanjutkan oleh guru dan masyarakat. Sopan 
santun harus ditanamkan pada anak sedini mungkin. Sebab sopan santun dan tata krama adalah perwujudan dari jiwa yang berisi nilai moral. Selanjutnya moral akan turut berkembang dengan yang lain dan akan dijadikan nilai sebagai pedoman dalam perilaku keseharian, Achir (dalam Junaidi, 2010). Ajarkan anak bersyukur setelah memperoleh sesuatu, ajarkan kejujuran, sopan santun, mencintai sesama, memelihara, dan memperbaiki.

2. Mendisiplinkan Anak

Dengan penerapan disiplin pada anak sejak dini, akan menumbuhkan pribadi anak yang mandiri. Seorang anak akan belajar berperilaku dengan cara yang diterima masyarakat, dan sebagai hasilnya anak anak dapat diterima oleh anggota kelompok sosial mereka. Prinsip disiplin harus dibuat sangat individu sesuai kebutuhan masing-masing anak dan keluarga.

3. Menyayangi anak secara wajar

Bagi ayah dan ibu yang bekerja sepanjang hari, atau mempunyai aktivitas sosial atau organisasi yang berlebihan kebanyakan menitipkan anaknya pada ibu pengganti. Berikanlah kasih sayang sewajarnya kepada anak walau sepanjang hari kedua ibunya bekerja.

4. Menghindari pemberian lebel "malas" pada anak

Banyak ibu memberikan lebel pada anaknya "malas". Sebutan ini dapat merugikan anak sebab membuat anak kurang berusaha karena 
upaya yang dilakukannya tidak akan diperhatikan. Hal penting yang harus dilakukan ibu justru membangun semangat anak.

\section{Metode Penelitian}

Penelitian ini menggunakan metode kuantitatif deskriptif yaitu merupakan metode penelitian yang berusaha menggambarkan dan menginterprestasikan objek dengan apa adanya.(Sugiyono,2008:208). Penelitian deskriptif pada umumnya dilakukan dengan tujuan utama, yaitu menggambarkan secara sistematis fakta dan karakteristik objek atau subjek yang diteliti. Subjek Penelitian ini terdiri 37 orang ibu yang dipilih secara random. Penelitian ini menggunakan angket sebagai instrument penelitiannya dengan model Skala Guttman dan wawancara. Skala Guttman digunakan untuk mendapatkan jawaban yang tegas terhadap suatu permasalahan yang ditanyakan, dimana penelitian ini akan menggunakan jawaban ya-tidak untuk mengambil data dari subjek penelitian. Skor jawaban adalah skor yaitu skor satu untuk jawaban "ya" dan skor nol untuk jawaban "tidak". Teknik analisa data dari penelitian ini adalah dengan menggunakan rumus

$$
\mathrm{p}=\frac{f}{N} \mathrm{X} 100 \%
$$

Keterangan :

$$
\begin{array}{ll}
\text { P } & \text { : Persentase } \\
\text { N } \quad \text { : Skor tertinggi (Ideal) } \\
\text { f : Skor yang diperoleh.(Sudijono,2006:43) }
\end{array}
$$

Adapun indikator dari penelitian ini mengacu pada teori yang di kembangkan oleh Junaidi (2010). Berikut ini indikatornya: 
1. Penanaman pekerti sejak dini

2. Mendisiplinkan anak

3. Menyayangi anak secara wajar

4. Menghindari pemberian lebel pada anak

\section{Hasil Penelitian}

Berdasarkan hasil penelitian diketahui bahwa ibu berperan aktif dalam pembinaan kepribadian anak-anaknya. Hasil penelitian yang dikemukakan berikut merupakan hasil deskripsi data yang berorientasi dari tujuan penelitian ini.

1. Ibu telah melakukan pembinaan kepribadian pada anaknya melalui penanaman pekerti sejak dini. Penanaman pekerti sejak sedini mungkin ini bertujuan untuk membentuk akhlak mulia pada diri anak sehingga terwujud kepribadian yang baik pula dalam diri anak

2. Ibu juga melakukan pendisiplinan pada anak, walaupun diketahui bahwa masih ada beberapa ibu yang kesulitan dalam menerapkan disiplin pada anak-anaknya karena alasan tidak tega atau kasihan pada anaknya. Pendisiplinan ini penting untuk membentuk perilaku anak yang mana perilaku ini merupakan implementasi dari pengembangan kepribadian yang dimiliki anak.

3. Menyayangi anak secara wajar merupakan salah satu bagian dalam pembinaan kepribadian pada anak, melalui pemberian kasih sayang yang sewajarnya dapat membentuk karakter anak yang tidak manja. 
4. Pemberian lebel pada anak, seperti "kamu anak yang malas" atau "kamu anak nakal" masih dilakukan oleh ibu walaupun diketahui bahwa pemberian lebel pada anak dapat memberikan dampak yang tidak baik dalam pembentukan kepribadian anak.

Berdasarkan uraian di atas dapat disimpulkan bahwa ibu telah mengetahui peranannya dalam pembentukan kepribadian anak-anaknya.Ibu sebagai figur terdekat dengan anak ketika melaksanakan perannya dengan baik dalam membina kepribadian anak akan menghasilkan kepribadian yang baik pada diri anak. Pengetahuan ibu akan perannya dalam penanaman pekerti sejak dini dan pemberian kasih sayang yang wajar atau tidak berlebihan pada diri anak akan membantu anak untuk mengembangkan kepribadian positif anak. Namun perlu di waspadai keengganan ibu untuk menerapkan disiplin pada anak karena perasaan ketidaktegaan dan masih adanya ibu yang memberikan pelebelan pada diri anak memungkinkan ibu sulit melakukan pembinaan kepribadian yang seharusnya. Oleh karena itu para ibu di harapkan untuk mempunyai komitmen yang kuat dalam melaksanakan perannya dalam rangka melakukan pembinaan kepribadian anak-anaknya.

\section{Referensi :}

Lapandi, S. 2007. Peran Lingkungan Keluarga Dalam Membentuk Kepribadian Anak. http://salehlapandi.wordpress.com/2007/02/25.

Hurlock, E.B. 1994. Psikologi Perkembangan: Suatu Pendekatan Sepanjang Rentang Kehidupan. Jakarta: Erlangga. 
Junaidi, Wawan. 2010. Sikap Orang Tua Mendukung Pembentukan Kepribadian Anak. http://wawan-junaidi.blogspot.com/2010/02/htmt.

Sugiyono, 2007. Statistik Untuk Penelitian. Bandung: CV. Alfabeta.

Salahudin. A. 2010. Bimbingan dan Konseling. Bandung : CV Pustaka Setia.

Sjarkawi. 2008. Pembentukan Kepribadian Anak. Jakarta: PT Bumi Aksara.

Sullivan, H.S. 1980. The Interpersonal Theory of Psychiatry. London: Tavistock Publication Limited 



\title{
PERAN KELUARGA DALAM PEMBENTUKAN ORIENTASI \\ HOMOSEKSUAL PADA REMAJA PRIA \\ WAHYUNI CHRISTIANY MARTONO \\ PRODI. PG. PAUD FKIP - UNPAR
}

\begin{abstract}
Adolescent homosexual orientation, can be formed when a child gets the label from the environment. In addition, the treatment of family's environment to the boys including parenting style can also form the homosexual orientation in adolescence, then back to themselves in shaping their identity.
\end{abstract}

\begin{abstract}
ABSTRAK
Orientasi Homoseksual pada remaja laki-laki, dapat terbentuk ketika anak mendapat label dari lingkungannya. Selain itu, perilaku lingkungan keluarga terhadap anak-anak, termasuk pola asuh juga dapat membentuk orientasi homoseksual pada masa remaja. Pada akhirnya, kembali pada diri masing-masing remaja pria itu sendiri dalam membentuk identitas mereka.

Kata kunci: Remaja, Keluarga, Orientasi Homoseksual
\end{abstract}

\section{PENDAHULUAN}

Perkembangan yang terjadi di masyarakat saat ini, cenderung menggeser nilai-nilai yang sudah tertanam sebelumnya. Aturan-aturan dan norma-norma yang ada di masyarakat tidak lagi bersifat mengikat. Hal-hal yang dulu dianggap 
tabu pun perlahan menjadi bahasan yang dianggap biasa. Salah satu fenomena yang belakangan ini muncul sebagai bahasan yang banyak dibicarakan adalah keberadaan kaum homoseksual.

Topik mengenai kaum homoseksual saat ini sudah menjadi topik yang umum dibicarakan khususnya di negara-negara maju dan berkembang. Di Indonesia sendiri, 10 atau 20 tahun lalu keberadaan kaum homoseksual amatlah tersembunyi dan sepertinya tabu untuk dibicarakan apalagi homoseksual dianggap sebagai suatu penyimpangan dari segi seksualitas maupun agama. Seiring dengan berkembangnya zaman, baik di Indonesia maupun di negara-negara lain, homoseksual dipandang sebagai gaya hidup, sikap bangga, terbuka, dan kadang militan terhadap masyarakat (Dede dalam Devitasari, 2003). Kaum pria homoseksual menyebut diri mereka 'gay' dan kaum wanitanya menyebut diri mereka 'lesbian'.

Keberadaan kaum homoseksual saat ini semakin diterima dan dihargai oleh beberapa golongan masyarakat. Para homoseksual pun, terutama kaum gay juga sudah berani 'unjuk gigi', mereka tidak segan lagi untuk tampil di muka umum dengan menunjukkan 'keberbedaan' mereka. Namun masih terdapat kesalahpahaman dalam masyarakat yang mengidentikkan kaum homoseksual dengan transeksual (waria). Padahal terdapat perbedaan yang mendasar antara keduanya. Menurut Kelly (dalam Devitasari, 2003) pada kaum transeksual terdapat derajat ketidak- nyamanan yang tinggi terhadap identitasnya, sebagai laki-laki dan perempuan atau dengan perkataan lain identitas gender mereka tidak sesuai dengan identitas biologis yang mereka miliki. Sedangkan, identitas gender 
kaum homoseksual konsisten dengan anatomi gender yang mereka miliki (Nevid dkk, dalam Devitasari, 2003).

Meskipun demikian, saat ini baik kaum transeksual maupun kaum homoseksual memiliki kesamaaan, yaitu sama-sama memiliki keberanian untuk menampilkan keberadaannya. Terutama untuk kaum homoseksual, keberanian menampilkan diri ini bukan hanya dimiliki oleh mereka yang sudah tergolong dewasa tetapi juga pada mereka yang masih remaja. Padahal menurut Greene dan Herek (1994) pada masa remaja orientasi seksual baru mulai terbentuk.

\section{TINJAUAN TEORI}

\section{REMAJA}

\section{Definisi}

Papalia (2010) dalam buku Human Development mengungkapkan,

"Adolescence is developmental transition between childhood and adulthood entailing mayor physical, cognitive and psychosocial changes"

Remaja adalah suatu masa dalam rentang pekembangan yang merupakan masa transisi antara masa kanak-kanak (childhood) dan masa dewasa (adulthood), meliputi perubahan fisik, kognitif, maupun psikososialnya. Masa remaja biasanya disebut juga sebagai masa pubertas; masa di mana individu mengalami kematangan seksual dan mampu bereproduksi (menghasilkan anak). Kata pubertas sendiri berasal dari kata puber (pubescent) yang dalam bahasa Latin disebut juga pubescere yang artinya mendapatkan pubes (rambut kemaluan). 
Dalam Papalia (2010), mendefinisikan remaja berkisar antara usia 11 hingga 19 atau 20 tahun.

G. Stanley Hall (1844-1924) yang dikenal sebagai bapak psikologi remaja memiliki definisi lain mengenai remaja,

"adolescence is the stage of life that characterized by 'strom and stress' ,that most teens are by nature moody and untrustworthy"

Menurutnya remaja adalah suatu tahap dalam kehidupan yang ditandai oleh "strom and stress" yakni suatu keadaan di mana remaja masih tidak konsisten (dipengaruhi mood) dan seringkali mengalami stress yang berlebihan (karena tidak bisa menikmati keadaan-keadaan "buruk" yang terjadi dalam hidupnya).

Melalui berbagai definisi yang ada, dapat kita rumuskan bahwa definisi remaja yang dipakai dalam pembahasan ini, yakni suatu tahap pada rentang perkembangan manusia yang ditandai dengan diperolehnya kematangan seksual (mampu bereproduksi) dan meliputi perubahan-perubahan yang terjadi pada aspek fisik, kognitif, maupun psikososialnya (tahap "strom and stress").

\section{Karakteristik}

Seorang psikolog bernama Erik Erikson menitikberatkan perkembangan manusia khususnya perkembangan psikososialnya pada pencarian identitas diri ('siapa saya?’ sebagai konsep yang sesuai mengenai diri sendiri, yang dibangun berdasarkan tujuan yang ingin dicapai, nilai-nilai, serta keyakinan yang dianut). Dalam teorinya ia menungkapkan delapan tahap perkembangan manusia dalam mencapai identitasnya mulai dari lahir sampai mati. 
1. Basic Trust vs Mistrust

\section{(lahir-1 tahun)}

Tahapan paling awal di mana individu mulai menanamkan kepercayaan pada orang lain (trust) disertai dengan sikap waspada (mistrust).

\section{Autonomy vs Shame and Doubt (2-3 tahun)}

Tahapan di mana individu belajar untuk mandiri, mereka juga mulai menjumpai aturan-atauran.

\section{Initiative vs Guilt (4-5 tahun)}

Individu mengalami pertumbuhan yang cukup pesat, ada kemajuankemajuan yang dicapai khususnya yang berkaitan dengan kreativitas dan imajinasi.

4. Industry vs Inferiority (6 tahun-pubertas)

Individu memiliki keinginan untuk masuk dunia pengetahuan dan pekerjaan.

\section{Identity vs Identity Diffusion (remaja)}

Individu mengintegrasikan identifikasi-identifikasi yang dibawa dari masa kanak-kanak menjadi suatu identitas diri (menjawa pertanyaan 'siapa saya?')

\section{Intimacy Solidarity vs Isolation (dewasa muda)}

Individu menjalin kebersamaan yang intim dengan sesamanya (teman, keluarga, dll). 


\section{Generativity vs Stagnation and Self Absorption (dewasa menengah)}

Tahapan di mana individu memiliki produktivitas yang tinggi, minat berkembang pesat, memiliki keinginan untuk membimbing generasi berikutnya.

\section{Intergrity vs Despair (dewasa akhir)}

Tahapan akhir sebagai integrasi dari semua tahapan sebelumnya di mana individu menerima dan menghargai hidupnya atau menyesali hidupnya dan merasa takut pada kematian.

Masa remaja menurut Erikson adalah masa untuk menyelesaikan krisis “identity vs identity diffusion". Remaja harus mampu menyusun atau membentuk identitas dirinya sendiri berdasarkan identifikasi-identifikasi yang sudah ia peroleh dari masa kanak-kanak mencakup kemampuan, kebutuhan, minat serta tujuan yang ingin dicapai. Apabila remaja tidak mampu membentuk identitasnya, mereka akan menghadapi "identity diffusion", yakni suatu keadaan tanpa ada krisis maupun komitmen (cuek, pasrah, berprinsip 'lihat nanti saja') dalam menjalani kehidupan sehari-hari, karena mereka tidak tahu siapa diri mereka; minat, kebutuhan maupun tujuan hidupnya.

Berdasarkan penelitian yang dilakukan oleh seorang psikolog James A. Marcia (dalam Papalia, 2010) status perkembangan ego seorang remaja bergantung dari ada tidaknya komitmen dan krisis. Marcia membedakan hal ini ke dalam empat status identitas:

1. Identity Achievement (adanya krisis yang mengantarkan ke pembentukan komitmen). Kepribadian remaja pada tingkat ini memiliki perkembangan 
ego yang tinggi, penalaran moral yang baik, keyakinan diri, harga diri, dan pengendalian stress yang baik serta dapat membina hubungan intim yang baik. Orang tua berperan dalam memberikan otonomi (tipe authoritative) juga membina hubungan dengan guru-guru anaknya. Adanya perbedaan pendapat antara anak dan orang tua dieksplorasi dalam konteks yang saling menguntungkan.

2. Foreclosure (adanya komitmen tanpa disertai krisis). Kepribadian remaja pada tingkat ini sangat penurut pada otoritas. Sangat tergantung pada orang lain, terutama orang tua, dan memiliki tingkat kecemasan yang rendah. Orang tua sangat berpengaruh terhadap diri anak bahkan pengaruhnya cenderung berlebihan. Remaja dengan tingkatan ini berasal dari keluarga yang authoritarian, yang menghindari munculnya perbedaan.

3. Moratorium (adanya krisis namun belum disertasi komitmen). Remaja pada tingkat ini memiliki level kecemasan yang lebih tinggi dan merasa takut akan kesuksesan. Memiliki level perkembangan ego yang tinggi penalaran moral dan penghargaan diri yang positif. Mereka sering berjuang melawan otoritas orang tua.

4. Identity Difussion (belum ada komitmen, belum pula ada krisis). Remaja pada tingkat ini cenderung tidak bahagia karena memiliki tingkat perkembangan ego yang rendah, begitu pula dalam penalaran moral, kompleksitas pemikiran, dan keyakinan diri. Mereka juga memiliki kemampuan kooperatif yang rendah. Orang tua mereka tidak peduli akan 
masa depan anaknya dan menyerahkan segala keputusan di tangan anaknya dan cenderung membiarkan (tipe permissive).

Remaja membentuk identitasnya tidak melalui modelling, peniruan pada model terhadap orang lain seperti yang dilakukan anak-anak. Tetapi melalui modifikasi pengumpulan dan penyatuan pengenalan-pengenalan awal menjadi struktur psikologi baru yang berkembang lebih baik dari sekedar rangkuman biasa. (Papalia, 2010)

\section{Peran Orang Tua Dalam perkembangan Psikologis Anak Peran Ibu}

Peran seorang ibu sangat penting bagi perkembangan anak. Pemberian pangan bukanlah satu-satunya hal yang perlu didapatkan seorang anak dari ibunya, bukan pula yang paling penting. Mothering juga meliputi kontak tubuh yang nyaman antara ibu dengan anaknya. Seorang anak memiliki kebutuhan sosial yang perlu dipuaskan agar mereka dapat tumbuh dewasa dengan normal.

\section{Peran Ayah}

Peran ayah, seperti juga peran ibu, mendatangkan komitmen emosional, dan seringkali terlibat secara langsung dalam pengawasan dan pendidikan anakanak (Engle \& Breaux dalam Devitasari, 2003). Namun, meskipun peran ayah bervariasi dalam berbagai kebudayaan, wanita tetap merupakan sumber rasa sayang primer anak dalam sebagian besar kebudayaan.

Keterlibatan seorang ayah yang rutin dan positif dengan anaknya sejak infancy secara langsung berhuibungan dengan well-being serta perkembangan 
kognitif dan psikososial si anak (Cabrera et al., dalam Devitasari, 2003). Ketidakberadaan figur ayah dapat mempengaruhi anak dalam banyak hal, dari tekanan buruknya ekonomi keluarga hingga psikologis (Papalia, 2010).

\section{Pola Pengasuhan Orang tua}

Menurut Dr. Diana Baumrind, pola pengasuhan orang tua dapat dibagi menjadi tiga kategori. yaitu Authoritarian Parent (otoriter), Permissive Parent (permisif), dan Authoritative Parent (otoritatif).

\section{A. Authoritarian Parent (otoriter)}

Orang tua yang otoriter memberlakukan peraturan-peraturan ketat dan menuntut agar peraturan-peratuaran harus dipatuhi. Mereka yakin bahwa anakanak harus "berada di tempat yang telah ditentukan" dan tidak boleh menyuarakan pendapatnya.

\section{B. Permissive Parent (permisif)}

Orang tua berusaha menerima dan mendidik sebaik mungkin, tetapi cenderung sangat pasif ketika sampai ke masalah penetapan batas-batas atau menanggapi ketidakpatuhan

Menurut Baumrind anak yang didik dengan gaya permisif akan menjadi anak yang kurang eksploratif, self-reliant, dan kurang kontrol diri.

\section{Authoritative Parent (otoritatif)}

Orang tua dengan gaya otoritatif berusaha menyeimbangkan antara batasbatas yang jelas dan lingkungan rumah yang baik untuk tumbuh.

Orang tua yang menjalankan gaya otoritatif akan membentuk anak-anak menjadi lebih percaya diri, mandiri, imajinatif, mudah beradaptasi, dan disukai 
banyak orang, yakni anak-anak yang memiliki kecerdasan emosional berderajat tinggi.

\section{Keluarga Bermasalah}

Beberapa keluarga bermasalah umumnya melakukan kesalahan dalam memberikan treatment secara emosional. Emotional Maltreatment meliputi aksi penyiksaan ataupun pengabaian terhadap anak yang disebabkan oleh tingkah laku, kognisi, emosional maupun gangguan mental. Hal ini dapat meliputi penolakan, terorisme, isolasi, eksploitasi, penghinaan, pencelaan, dan kegagalan dalam memberi dorongan dan asupan support, kasih sayang, serta afeksi. (Dubowitz, USDHHS, 1999 dalam Papalia, 2010)

\section{HOMOSEKSUAL}

\section{Definisi}

Homoseksualitas adalah ketertarikan seksual atau preference kepada jenis kelamin yang sejenis. (Miracle, 2003)

Dalam buku Human Sexuality in a World of Diversity (Rathus, 1993), dikatakan bahwa pada umumnya remaja laki-laki yang memiliki kecenderungan homoseksual merasakan ibunya mendominasi, overprotektif, dan membuat mereka tergantung; mereka melihat ayahnya kurang memiliki peran, dan tidak memedulikan mereka serta membuat mereka merasa tidak diinginkan.

\section{Faktor Penyebab Seseorang Memiliki Orientasi Homoseksual}

\section{Teori Psikoanalisa}


Menurut Teori Psikoanalisa Sigmund Freud, laki-laki homoseksual memiliki hubungan yang dekat (close-binding) dengan ibunya. Dan cenderung jauh atau bermusuhan dengan ayahnya. Hal ini menyebabakan pertalian yang kuat dengan ibu mereka dan ketidakmampuan membina hubungan dengan wanita lain.

Menurut penelitian lintas budaya, kaum homoseksual secara umum ditemukan di masyarakat yang memiliki budaya bahwa ayah tidak terbiasa atau sangat minim terlibat dalam pengasuhan anak (Stockard dan Johnson dalam Miller, 1993). Sehingga anak laki-laki akan menganggap ayahnya sebagai orang lain yang terpisah dengan keluarganya.

\section{Learning Theory}

Behaviorist menekankan pentingnya proses belajar dalam hal perkembangan orientasi seksual seseorang. Pendekatan teori learning menganggap homoseksualitas sebagai bentuk tingkah laku yang normal dan menganggap heteroseksual bukan sesuatu yang bersifat inborn, namun sama halnya dengan homoseksual, yaitu bersifat dipelajari.

\section{Sociological Theory}

Sociologist menekankan pada efek dari labelling terhadap homoseksual. Label yang diberikan kepada kaum homoseksual memiliki dampak yang cukup besar dalam kehidupan bermasyarakat. Pemberian label 'homoseksual' memiliki konotasi negatif dan menunjukkan sikap negatif masyarakat terhadap para homoseksual. 
Orientasi homoseksual dapat terjadi bila seorang anak pernah mendapat label dari lingkungannya bahwa ia adalah seorang yang homoseksual. Kasus seperti ini biasa terjadi pada anak laki-laki yang memiliki kemampuan kurang di bidang olahraaga.

Tahap Perkembangan Homoseksual (King dalam Miracle, 2003)

1. Recognition of being homosexuality. Tahap ini berkisar pada awal masa anak-anak sampai remaja atau lebih. Pada tahap ini mereka umumnya merasa kesepian, sedih, dan bingung dengan keadaan atau pengalaman yang dilaluinya.

2. Getting to know other homosexuals pada tahap ini mereka umumnya telah mengalami hubungan romantis bahkan hubungan seksual lainnya dengan sesama jenis.

3. Telling family and friends pada tahap ini kaum homoseksual tidak dapat membawa mereka untuk melakukan hubungan lebih jauh dan lebih lama lagi jika memungkinkan.

4. Complete openness. Pada tahap ini mereka umumnya telah memberitahukan keadaan mereka pada teman sebaya, atasan mereka, maupun relasi lainnya yang mereka anggap telah dapat menerima mereka. Remaja gay seringkali membentuk sejumlah pertahanan terhadap pengenalan dirinya dan pemberian label. Mereka melakukan passing, yakni proses menyembunyikan identitas sosial seseorang yang sebenarnya, termasuk di dalamnya identitasnya sebagai homoseksual (Savin-Williams \& Rodriguez dalam Greene and Herek,1994). 
Menurut Cass dalam Greene and Herek (1994), identitas seksual pada seseorang bukanlah sesuatu yang permanen tetap dalam diri meskipun identitas ini mungkin sudah terinternalisasi untuk jangka waktu yang lama dan relatif menetap pada diri seseorang.

Seseorang akan dapat merubah sendiri orientasi seksualnya menjadi derajat tertentu tergantung pada bagaimana orang itu memandang dirinya. (Strokes, Damon \& McKirnan dalam Greene and Herek, 1994).

\section{PENUTUP}

Terdapat beberapa hal yang mempengaruhi seorang remaja memiliki orientasi seksual terhadap sesama jenis, di antaranya, akibat rasa keingintahuan terhadap kaum tersebut (pada akhirnya terperosok sendiri), beberapa lagi menjadi homoseksual (gay) karena pengaruh lingkungan sosialnya. Dalam hal lingkungan sosial, keluarga sebagai significant other memiliki pengaruh yang besar terhadap perkembangan psikososial seorang remaja. Karena, didikan orang tua yang telah terinternalisasi sejak kecil.

\section{Referensi :}

Devitasari, M. R. (2003). Proses Pembentukan Identitas Seksual pada Gay. Depok: Fakultas Psikologi.

Duek, Jerome B. 1996. Adolescence Development and Behavior. New Jersey: Prentice-Hall, Inc.

Greene, B. \& Flerek, G. M (Eds.). (1994). Psychological Perspectives on Lesbian and Gay Issues: vol. 1. Lesbian \&Gay Psychology: Theory, Research, and Clinical Aplications. Thousand Oaks, CA: Sage 
Miller, Patricia H. 1993. Theories of Developmental Psychology. USA: W. H. Freeman and Company.

Miracle, Tina S. 2003. Human Sexuality: Meeting Your Basic Needs. New Jersey: Pearson Education, Inc.

Ovesey, L. 1969. Homosexuality and Pseudohomosexuality. USA: Science House, Inc.

Papalia, D. E., dkk. 2010. Human Development $9^{\text {th }}$ Edition. New York: Mc. Graw-Hill Companies.

Rathus, Spencer A., dkk. 1993. Human Sexuality in A World of Diversity. Massachusets: Allyn and Bacon.

Santrock, John W. 2003. Adolescence Pekembangan Remaja. Jakarta: Erlangga. 
PENGANGKATAN DAMANG KEPALA ADAT DI

\author{
KECAMATAN JEKAN RAYA KOTA PALANGKA RAYA
}

YETWIRANI LAMPE

Prodi PPKN FKIP - UNPAR

A B S T R A K : Permasalahan yang diangkat dalam penelitian ini adalah bagaimana pelaksanaan pengangkatan Damang Kepala Adat di Kecamatan Jekan Raya Kota Palangka Raya berdasarkan Perda No. 16 Tahun 2008. Faktor yang mendukung dan menghambat dalam implementasi kebijakan dalam pelaksanaannya. Penelitian ini dilakukan dengan tujuan untuk mendeskripsikan dan menganalisis proses pengangkatan Damang Kepala Adat berdasarkan Perda No. 16 Tahun 2008 serta faktor-faktor pendukung dan penghambat dalam pelaksanaan pengangkatan Damang Kepala Adat.

Penelitian ini menggunakan pendekatan kualitatif - deskriptif, data dikumpulkan melalui wawancara, observasi, dan dokumentasi. Pengambilan sampel dilakukan secara purposive sampel terdiri dari : Camat, Sekretaris Camat, Lurah, Kasi Pemerintahan Umum Kota, Kasi Pemerintahan Kecamatan, Kasi Pemerintahan Kelurahan, Ketua Dewan Adat Dayak Propinsi Kalimantan Tengah, Wakil Ketua II Dewan Adat Dayak Kota Palangka Raya, Dewan Adat Dayak Kecamatan, Damang Kepala Adat, Mantir Adat Kecamatan, Mantir Adat Kelurahan di Kecamatan Jekan Raya.

Teknik analisis data menggunakan analisis interaktif dari Miles dan Huberman, dimana data yang telah dikumpulkan dianalisa dengan cara reduksi data, penyajian data, dan penarikan kesimpulan.

Hasil penelitian menunjukkan bahwa (1). Dari segi proses penjaringan Calon Damang Kepala Adat yang akan berhak dipilih untuk diangkat menjadi Damang Kepala Adat, sangat terbatas, dan yang bisa dicalonkan hanya yang pernah atau sedang duduk sebagai anggota Kerapatan Mantir Adat, sehingga tidak banyak pilihan. (2) Dilihat dari proses pelaksanaan penilaian Calon Damang Kepala Adat, maka Calon yang terjaring sudah memenuhi persyaratan yang sudah diatur dalam Pasal 17, dan 19 Perda No. 16 Tahun 2008. (3). Dilihat dari pelaksanaan pemilihan Calon Damang Kepala Adat sudah memenuhi prosedur pemilihan yang sudah diatur dalam Pasal 22 Perda No. 16 Tahun 2008. (4). Hasil pemilihan, nama Damang Kepala Adat (terpilih) dituangkan kedalam Berita Acara dan laporannya disampaikan kepada Walikota Kota Palangka Raya, sebagai dasar untuk menerbitkan Surat Keputusan Pengangkatan Damang Kepala Adat. (5). Faktor yang mendukung, adalah adanya Perda No. 16 Tahun 2008 sebagai Pedoman Utama dalam Pengangkatan Damang Kepala Adat. Kemitraan dengan Pemerintahan Kecamatan Jekan Raya dalam memfasilitasi Pemilihan dan Pengangkatan Damang Kepala Adat, melalui Panitia Pemilihan yang dibentuk oleh Camat Jekan Raya. (6). Adanya dana yang tersedia yang berasal dari APBD untuk penyelenggaraan pemilihan dan pengangkatan Damang Kepala Adat, dalam artian untuk biaya pelaksanaan pemilihan dan honorarium Panitia Pemilihan. (7). Faktor penghambat belum ada pedoman yang khusus tentang tata cara pengaturan penjaringan, sehingga bakal calon Damang Kepala Adat sangat terbatas dan tidak banyak pilihan, dan kurangnya sosialisasi sampai ke level 
bawah ke Kelurahan (8). Tidak adanya standar penilaian yang jelas mengenai persyaratan yang harus dimiliki oleh calon Damang Kepala Adat seperti yang diatur dalam Pasal 17 ayat (1) c. Perda No. 16 Tahun 2008, mengingat tugas dan fungsi yang diemban oleh Damang Kepala Adat sebagai Pemangku Adat cukup berat seperti yang diatur dalam Pasal 7, dan 8 Perda No. 16 Tahun 2008.

Diharapkan dimasa yang akan datang hendaknya penjaringan Calon Damang Kepala Adat yang akan dipilih dan diangkat menjadi Damang Kepala Adat, disosialisasi lebih aktif lagi sampai ke level bawah sampai ke Kelurahan, agar cukup banyak pilihan. Perlu adanya standar yang jelas untuk menilai mengenai persyaratan yang harus dimiliki seperti yang diatur dalam Pasal 17 ayat (1) c Perda No. 16 Tahun 2008. Perlu adanya pembekalan dan pelatihan untuk meningkatkan pengetahuan mengenai adat istiadat, Hukum Adat Dayak, kebiasaan, dan kearifan lokal lainnya berkaitan dengan tugas dan fungsi Damang Kepala Adat baik bagi para Damang Kepala Adat maupun bagi Calon Damang Kepala Adat agar lebih berkualitas untuk menghadapi perkembangan ilmu pengetahuan, teknologi dan komunikasi yang mengglobal.

Keywords : Implementasi Kebijakan, Pengangkatan Damang Kepala Adat.

Sebagaimana kita ketahui bahwa Negara kita terdiri dari beribu-ribu pulau dan berbagai suku bangsa, ras, golongan, agama, dan budaya dengan adat istiadat yang berbeda-beda pula. Keanekaragaman budaya merupakan bagian dari kekayaan bangsa kita yang tiada taranya sebagai suatu kekuatan untuk kemajuan bangsa kita menjadi bangsa yang besar, sejahtewra, adil dan makmur apabila dapat kita kelola dengan baik. Sebaliknya apabila keanekaragaman budaya tidak dapat kita kelola dengan baik niscaya akan mendatangkan disharmoni antar suku bangsa, ras, golongan, dan agama. Bukan kemajuan yang kita alami melainkan kemunduran budaya dan bahkan kehancuran budaya dalam kehidupan berbangsa dan bernegara.

Kata "budaya" berasal dari bahasa Sansekerta buddhyah, yaitu bentuk jamak dari buddhi yang berarti "budi" atau "akal" ke-budaya-an dapat diartikan: "hal-hal yang bersangkutan dengan "akal". Disini kata budaya hanya dipakai sebagai suatu singkatan saja dari "kebudayaan" dengan arti yang sama. "Kebudayaan" adalah: "keseluruhan sistem gagasan, tindakan dan hasil karya manusia dalam kehidupan masyarakat yang dijadikan milik diri manusia dengan belajar”. (Koentjaraningrat, 2009 : 144, 146). Selanjutnya, menurut Maas. D.P (1986 : 135), mengatakan bahwa: 
Dilihat dari aspeknya, kebudayaan terbagi atas dua kelompok. Aspek pertama ialah kebudayaan nonmateri. Kebudayaan ini hasil perilaku rohani, terutama hasil perasaan dan pikiran. Wujudnya antara lain ialah sistem nilai, ilmu dan pengetahuan, sikap dan pandangan. Hasil perilaku jasmaniah melahirkan kebudayaan dalam bentuk benda-benda kebudayaan yang bersifat materi. Kebudayaan ini termasuk jenis kebudayaan materi. Contohnya antara lain ialah mobil, rumah, jembatan.

Sehubungan dengan kebudayaan nonmateri yang berkaitan dengan sistem nilai khususnya, hal ini menginngatkan kita pada pernyataan Prof. Dr. Tamrin Amal Tomagola dalam siding Kasus Video Asusila Nasriel Irham (Ariel Peterpan) tanggal 2 Desember 2010, dimana sosiolog Universitas Indonesia membuat pernyataan dan keterangan bahwa: "Dikalangan Masyarakat Dayak Yang Menganggap Bersanggama Tanpa Diikat Perkawinan Sebagai Hal Biasa", dianggap sangat melukai perasaan, merendahkan harkat dan martabat serta pelecehan terhadap Adat Istiadat Suku Dayak yang mengedepankan prinsip "Belom Bahadat" (hidup bertata krama dan beradat) dalam segi-segi kehidupan masyarakat Dayak. Sehingga atas pernyataan dan tindakan yang bersangkutan diwajibkan dan diminta untuk mempertanggungjawabkan ucapan atau pernyataannya sesuai Hukum Adat Dayak dihadapan seluruh elemen suku Dayak yang disampaikan melalui media masa elektronik dan cetak local dan nasional. Kemudian yang bersangkutan diwajibkan mempertanggungjawabkan dihadapan Majelis Sidang Adat Dayak yang memutuskan sanksi, denda, dan hukuman adat dikenakan kepada yang bersangkutan. Persidangan diberi nama: Persidangan Adat Dayak Maniring Tuntang Manetes Hinting Bunu antara masyarakat Dayak dan Tamrin. Secara harapiah artinya memutus dendam yang berkepanjangan dalam menuju perdamaian kea rah yang lebih baik antara masyarakat Dayak dan Tamrin Amal Tomagola. Dari peristiwa atau kejadian tersebut di atas 
menunjukkan pentingnya mengetahui dan memahami keanekaragaman budaya bangsa kita, agar peristiwa tersebut di atas atau semacamnya tidak terulang lagi, sehingga masyarakat dan bangsa kita terhindar dari disharmoni, tetapi bangsa kita menjadi bangsa yang tenang, tentram dan harmonis, menjadi bangsa yang besar, sejahtera, adil dan makmur.

Dengan dikeluarkannya UU No.22/1999 tentang Pemerintahan Daerah tanggal 7 Mei 1999 oleh Presiden B.J. Habibi, pelaksanaan otonomi daerah adalah salah satu amanat reformasi yang fundamental.

Perlu kiranya untuk memahami hakekat atau makna filosofis dari prinsip keotonomian, seperti dikemukakan oleh Faisal H. Basri (dalam Piliang, 2003:viii) sebagai berikut:

Pada tingkat terendah, otonomi mengacu pada individu sebagai perwujudan dari free will yang melekat pada diri-diri manusia sebagai salah satu anugerah paling berharga dari Sang Pencipta. Free will inilah yang memungkinkan individu-individu menjadi otonom sehingga mereka bias mengaktualisasikan segala potensi terbaik yang ada didalam dirinya secara optimal. Individu-individu yang otonom inilah yang selanjutnya membentuk komunitas yang otonom,dan akhirnya bangsa yang mandiri serta unggul.

Dari uraian diatas dapat ditarik suatu pemahaman bahwa individu-individu yang otonom menjadi modal dasar bagi perwujudan otonomi daerah yang hakiki. Individuindividu yang otonom yang membentuk komunitas otonom, mengandung arti bahwa kehidupan manusia pada dasarnya dijalankan melalui kelembagaan atau organisasi kemasyarakatan atau kelompok.

Provinsi Kalimantan Tengah sebagai bagian wilayah Negara Kesatuan Republik Indonesia (NKRI) di anugerahi oleh Tuhan Yang Maha Esa sumber daya alam yang melimpah beserta dengan kekhasan budaya, adat-istiadat, kebiasaan dan hokum adatnya. 
Di dalam kehidupan masyarakat local telah tumbuh komunitas masyarakat atau kelompok-kelompok masyarakat adat yang dipimpin oleh kepala kelompok/kepala adat. Dalam perkembangannya telah tumbuh secara tradisional lembaga adat dayak bersamaan dengan tumbuh dan berkembangnya masyarakat adat. Lembaga adat ini selanjutnya berkembang menjadi sebuah Kelembagaan Adat Dayak yang kita kenal sekarang ini. Kelembagaan Adat Dayak ini dipimpin oleh seorang Damang Kepala Adat (disingkat Damang).

Sejak dikeluarkannya UU No. 22/1999 tentang Pemerintah Daerah, telah membuka kesempatan yang luas bagi masyarakat local/daerah di Propinsi Kalimantan Tengah untuk mengaktualisasikan semua potensi terbaiknya secara optimal menuju masyarakat madani atau Civil society, sesuai dengan aspek keragaman budaya lokal.

Kewenangan daerah otonom untuk mengatur dan mengurus kepentingan masyarakat setempat, menurut prakarsa sendiri berdasarkan aspirasi masyarakat dengan memperhatikan keragaman daerah, telah menjawab tuntutan reformasi berupa demokratisasi, keterbukaan, desentralisasi, pemerataan, dan lain-lain. Namun karena telah lama aspek-aspek keragaman daerah disingkirkan dalam upaya penguatan Negara kesatuan pada masa pemerintahan Orde Baru selama kurun waktu 32 tahun yang sentralistik, keanekaragaman budaya daerah jalan ditempat bahkan mengalami kemunduran, dan bias dikatakan mati suri.

Dalam rangka mengangkat, melestarikan, memberdayakan, dan mengembangkan potensi sosial budaya daerah, mengenai adat-istiadat, kebiasaan-kebiasaan dan hukum adat dipandang perlu dihidupkan/diaktifkan kembali Kelembagaan Adat Dayak di Kalimantan Tengah melalui peraturan daerah. Hal ini sejalan pula dengan Visi, Misi dan Program Pembangunan Kalteng 2005-2010, dalam program kerja khusus bidang social budaya dikatakan: memberikan peran yang penting dari para Damang, dalam rangka 
peningkatan peran social Damang dalam masyarakat. Damang Kepala Adat sebagai Pemimpin lembaga adat dayak sangat berperan dalam mengatur dan menata masyarakat adat, agar tumbuh kesadaran mengenai identitas dan jati diri masyarakat dayak sehingga tidak luntur dan tergerus oleh arus zaman yang mengglobal. Peran tersebut sangat penting dalam rangka penataan masyarakat adat sebagai mitra pemerintah. Oleh karena itu lembaga adat tersebut perlu terus didorong perannya dalam mendukung kelancaran dan keberhasilan penyelenggaraan roda pemerintah kearah yang lebih baik.

Dengan dikeluarkannya Peraturan daerah Propinsi Kalimantan Tengah No. 16 Tahun 2008 Tentang Kelembagaan Adat Dayak Kalimantan Tengah (Perda No. 16 Tahun 2008) secara legal formal menempatkan Dewan Adat Dayak dan Damang Kepala Adat (Damang) mempunyai Kedudukan, Tugas, dan Fungsi yang patut diperhitungkan oleh siapa saja dalam masyarakat Kalteng khususnya maupun diluar masyarakat Kalteng pada umumnya. Pasal 7 Perda No. 16 Tahun 2008 menetapkan:

(1). Damang Kepala Adat berkedudukan di ibu kota kecamatan sebagai mitra Camat dan mitra Dewan Adat Dayak kecamatan, bertugas dalam bidang pelestarian, pengembangan, dan pemberdayaan, adat-istiadat, kebiasaankebiasaan dan berfungsi sebagai penegak hokum adat dayak dalam wilayah Kedamangan bersangkutan.

Sehubungan dengan fungsi Damang, dalam pasal 9 menetapkan bahwa:

(2). Fungsi Damang Kepala Adat adalah mengurus, melestarikan, memberdayakan, dan mengembangkan adat-istiadat kebiasaan-kebiasaan, hukum adat dan lembaga kedamangan yang dipimpinnya. Menegakkan hukum adat dengan menangani kasus dan atau sengketa berdasarkan hukum adat dan merupakan peradilan adat tingkat terakhir, dan sebagai penengah dan 
pendamai atas sengketa yang timbul dalam masyarakat berdasarkan hukum adat.

(3) Selain fungsi sebagaimana dimaksudkan pada ayat (1), Damang Kepala Adat juga mempunyai fungsi selaku inisiator untuk membawa penyelesaian terakhir sengketa antara para Damang terkait tugas dan fungsinya kepada Dewan Adat Dayak Kabupaten/Kota.

Di era globalisasi ini, dimana perkembangan ilmu pengetahuan, teknologi dan informasi berkembang pesat, menyebabkan hubungan dunia luar seolah-seolah sudah tanpa batas lagi, apa yang terjadi dibelahan dunia luar dengan segera diketahui dibelahan dunia lainnya pada saat itu juga. Pesatnya perkembangan ilmu pengetahuan, teknologi dan informasi membawa perubahan yang cepat pula di segala bidang kehidupan umat manusia. Perubahan yang serba cepat dan kompleks dalam kehidupan umat manusia mendorong terjadinya persaingan yang semakin ketat baik di bidang politik, ekonomi, sosial, budaya, dan lain-lain.

Penjaringan dan pendaftaran bakal calon Damang :

Untuk melakukan penjaringan, Panitia Pemilihan membuka pendaftaran bakal Damang Kepala Adat. Panitia Pemilihan menyiapkan formulir pendaftaran dan syaratsyarat yang harus diisi dan dilengkapi oleh bakal calon Damang Kepala Adat. Hal ini sejalan dengan penuturan Mantir Adat Kelurahan Petuk Katimpun, sekaligus sebagai Wakil Ketua Panitia Pemilihan.

Pendaftaran pemilihan bakal calon Damang Kepala Adat :

Yang berhak memilih bakal calon Damang adalah semua Kepala Desa dan Lurat atau Pejabat Kepala Desa dan Pejabat Lurah, semua Ketua Badan Permusyawaratan Desa, Ketua Lembaga Kemasyarakatan Kelurahan, semua anggota Kerapatan Mantir 
Perdamaian Adat Kecamatan yang bersangkutan dan semua Ketua Kerapatan Mantir Perdamaian Adat Desa/Kelurahan wilayah Kedamangan yang bersangkutan.

Persyaratan administrasi bakal calon Damang Kepala Adat :

1. Calon Damang Kepala Adat adalah penduduk yang berasal dari Suku Dayak denga melengkapi persyaratan yang telah ditentukan.

2. Bakal calaon Damang Kepala Adat mengajukan permohonan secara tertulis kepada Panitia Pemilihan dengan dilengkapi persyaratan sebagaimana dimaksud pada ayat (1) sebanyak 4 (empat) rangkap dengan dibubuhi meterai Rp. 6.000,(enam ribu rupiah).

Penetapan calon Damang Kepala Adat :

Penetapan calon Damang Kepala Adat dilakukan oleh panitia pemilihan dengan menetapkan 3 orang calon Damang Kepala Adat yang berhak dipilih melalui pemilihan dengan Surat Keputusan Camat.

Pemilihan calon Damang Kepala Adat :

Pemilihan calon Damang Kepala Adat dilakukan dengan mengacu kepada pada pasal 22, 23, dan 24 Perda No. 16 Tahun 2008. Pelaksanaan pemilihan Damang Kepala Adat seperti pemilihan umum, sebagaimana mekanisme pemilihan umum, disediakan kotak suara.

\section{Pengangkatan Damang Kepala Adat :}

Dalam pasat 25 ayat (1), dikatakan : paling lambat 15 (lima belas) hari sejak diterimanya usulan dan Berita Acara hasil pemilihan Damang Kepala Adat, Bupati/Walikota segera menetapkan tentang pengangkatannya. Setelah Walikota Palangka Raya menerima dan meneliti Berita Acara dan laporan hasil pemilihan yang dikirim oleh Panitia Pemilihan Kecamatan Jekan Raya, dan ternyata tidak ada hal-hal yang bertentangan dalam 
pelaksanaan maka Walikota mengeluarkan Surat Keputusan Pengangkatan Damang Kepala Adat.

Pelantikan Damang Kepala Adat :

Untuk melaksanakan seluruh proses pemilihan dan pengangkatan Damang Kepala Adat tersebut diatas, panitia pemilihan memperoleh dana yang sudah dianggarkan melalui Anggaran Pendapatan dan Belanja Daerah (APBD) Kota Palangka Raya. Dana tersebut dimaksudkan untuk biaya operasional sekretariat, pelaksanaan pemilihan dan honorarium panitia pemilihan. Sehinggan untuk menjalankan tugas-tugas kepanitian tidak ada kendala yang berarti dalam masalah dana. Jadi dalam menjalankan tugas-tugasnya Panitia Pemilihan tidak ada kendala yang berarti dalam masalah dana, karena sudah ada mata anggarannya. Biaya operasional sekretariat seperti alat-alat tulis untuk menyiapkan formulir dan persyaratan yang harus diisi oleh calon Damang Kepala Adat, untu membuat undangan, pemberitahuan/pengumuman sampai ke tingkat kelurahan, surat suara, kotak suara. Untuk konsumsi rapat panitia pemilihan, sampai kepada biaya konsumsi saat pelaksanaan pemilihan, membuat Berita Acara dan Laporan Hasil pemilihan yang dikirimkan ke Walikota Palangka Raya dan Dewan Adat Dayak Kota Palangka Raya, serta untuk honorarium Panitia Pemilihan.

Faktor Pendukung :

1. Adanya Peraturan Daerah Provinsi Kalimantan Tengah No. 16 Tahun 2008, sebagai pedoman utama dalam pelaksanaan pengangkatan Damang Kepala Adat, dalam Perda ini telah mengatur tentang mekanisme pemilihan. Pembentukan Panitia Pemilihan, persyaratan yang harus dipenuhi oleh calon Damang Kepala Adat di wilayah Kecamatan Jekan Raya.

2. Perda No. 16 ini juga telah mengatur kemitraan antara Pemerintah Provinsi Kalimantan Tengah, Pemerintah Kota Palangka Raya, serta pemerintah 
Kecamatan Jekan Raya dengan Dewan Adat Dayak Provinsi Kalimantan Tengah, Dewan Adat Dayak Kota Palangka Raya, dan Dewan Adat Dayak Kecamatan, serta Lembaga Kedamangan di wilayah Kecamatan Jekan Raya.

3. Adanya alokasi dana yang berasal dari APBD Kota Palangka Raya, yang telah dianggarkan untuk pelaksanaan pemilihan. Dana tersebut dimaksudkan bagi biaya operasional sekretariat, penyelenggaraan pemilihan dan honorarium Panitia Pemilihan.

Faktor Penghambat :

1. Belum adanya pedoman yang standar untuk menilai calon Damang Kepala Adat, yang dikatakan : "memiliki pengalaman dan pengetahuan yang cukup luas mengenai adat isitiadat dan hukum adat Dayak setempat yang dibuktikan dengan mencantumkannya dalam daftar riwayat hidup", sebagaimana diatur dalam Pasal 17 ayat (1) c Perda No. 16 Tahun 2008. Hal ini jika dikaitkan dengan tugas dan fungsi Damang Kepala Adat yang cukup berat sebagai Pemangku Adat, seperti yang diatur dalam Pasal 7,8,9 Perda No. 16 Tahun 2008.

2. Terbatasnya calon Damang Kepala Adat yang berhasil dijaring, karena yang bisa mencalonkan diri menjadi Damang Kepala Adat hanya mereka yang pernah menjadi Lurah (mantan lurah), yang pernah menjadi Mantir Adat (mantan Mantir Adat), yang pernah bekerja dan berpengalaman di sekretariat Kedamangan, dan Mantir Adat Aktif.

3. Belum terbentuknya Dewan Adat Dayak Kecamatan, sebagai mitra Damang Kepala Adat, lembaga koordinasi dan supervisi bagi Dewan Adat Dayak dan Kerapatan Mantir Perdamaian Adat Desa/Kelurahan, demi membantu kelancaran tugas Damang Kepala Adat di bidang pemberdayaan, pelestarian, pengembangan, adat istiadat, kebiasaan-kebiasaan dan hukum adat Dayak di wilayah Kecamatan. 
4. Belum ada Perda Kota Palangka Raya tentang Kelembagaan Adat Dayak di Kota Palangka Raya, sebagai pedoman khusus dalam pelaksanaan pemilihan dan pengangkatan Damang Kepala Adat yang lalu.

\section{Daftar Referensi :}

Abdul Wahab, Solichin. 1990. Analisis Kebijaksanaan Negara. Jakarta: Rineka Cipta.

Abdurrahman. 2001. Revitalisasi Hukum Adat Masyarakat Dayak. Fakultas Hukum. Palangka Raya: Universitas Palangka Raya.

Arikunto, Suharsimi. 2006. Prosedur Penelitian, Edisi Revisi VI. Cetakan ketigabelas. Jakarta: Rineka Cipta.

Hermansyah U., 2002. Singer Dayak Ngaju Dalam Interaksi Sosial di Kelurahan Tangkiling Palangka Raya. Tesis Program Pascasarjana Universitas Padjajaran Bandung.

Peraturan Daerah Provinsi Kalimantan Tengah No. 16 Tahun 2008 Tentang Kelembagaan Adat Dayak.

Peraturan Daerah Provinsi Kalimantan Tengah No. 1 Tahun 2011 Tentang Perubahan Atas Peraturan Daerah Provinsi Kalimantan Tengah No. 16 Tahun 2008 Tentang Kelembagaan Adat. 